\title{
Cannabinoids and Epilepsy
}

\author{
Evan C. Rosenberg ${ }^{1} \cdot$ Richard W. Tsien ${ }^{1} \cdot$ Benjamin J. Whalley ${ }^{2} \cdot$ Orrin Devinsky $^{3}$
}

Published online: 18 August 2015

(C) The American Society for Experimental NeuroTherapeutics, Inc. 2015

\begin{abstract}
Cannabis has been used for centuries to treat seizures. Recent anecdotal reports, accumulating animal model data, and mechanistic insights have raised interest in cannabisbased antiepileptic therapies. In this study, we review current understanding of the endocannabinoid system, characterize the pro- and anticonvulsive effects of cannabinoids [e.g., $\Delta 9$-tetrahydrocannabinol and cannabidiol (CBD)], and highlight scientific evidence from pre-clinical and clinical trials of cannabinoids in epilepsy. These studies suggest that CBD avoids the psychoactive effects of the endocannabinoid system to provide a well-tolerated, promising therapeutic for the treatment of seizures, while whole-plant cannabis can both contribute to and reduce seizures. Finally, we discuss results from a new multicenter, open-label study using CBD in a population with treatment-resistant epilepsy. In all, we seek to evaluate our current understanding of cannabinoids in epilepsy and guide future basic science and clinical studies.
\end{abstract}

Keywords Epilepsy · seizures · cannabinoids · cannabidiol · $\mathrm{THC} \cdot$ cannabis

Electronic supplementary material The online version of this article (doi:10.1007/s13311-015-0375-5) contains supplementary material, which is available to authorized users.

Orrin Devinsky

od4@nyu.edu

1 Department of Neuroscience and Physiology, Neuroscience Institute, NYU Langone Medical Center, New York, NY 10016, USA

2 School of Pharmacy, The University of Reading, Whiteknights, Reading RG6 6AP, UK

3 Department of Neurology, Comprehensive Epilepsy Center, New York University School of Medicine, New York, NY 10016, UK

\section{Introduction}

Epilepsy affects 2.9 million people in the USA and 65 million people worldwide (cdc.gov/epilepsy). One in 26 people in the USA will develop epilepsy in their lifetime [1]. Characterized by recurrent seizures, epilepsy encompasses multiple disorders caused by varied etiologies, including genetic syndromes, stroke, infection, and traumatic brain injury. Many patients with epilepsy also have sensorimotor, cognitive, psychological, psychiatric, and social impairments, as well as impaired quality of life and an increased risk of premature death [1]. While epilepsy can affect patients of all ages, it most commonly affects children, the elderly, and individuals with low socioeconomic status. The estimated direct and indirect annual cost of epilepsy in the U.S. is $\$ 15.5$ billion (cdc.gov/ epilepsy).

While many drugs can limit seizures, no drug can prevent the underlying cause of epilepsy or the development of epilepsy (epileptogenesis) in patients who are at risk (e.g., after head trauma). A third of patients remain pharmacoresistant, failing to achieve sustained seizure freedom after 2 or more adequately chosen, tolerated, and appropriately used antiepileptic drugs (AEDs; more accurately termed antiseizure drugs) [2-4]. Patients resistant to multiple AEDs have an increased risk for sudden unexpected death in epilepsy and other forms of epilepsy-related mortality $[5,6]$, as well as impairments in psychosocial, behavioral, and cognitive functions [3, 7-9]. For many patients, epilepsy is a progressive disorder associated with ongoing loss of brain tissue and function. Finally, multidrug combinations and high dosages cause more severe side effects, a particular problem in patients with treatmentresistant epilepsies. Assessing the side effects of AEDs is especially challenging in patients on long-term AEDs as any 'baseline' may be many years past and even intelligent adults, parents, and physicians may fail to appreciate chronic adverse 
effects. The available AEDs fail to meet the clinical needs for both efficacy and safety [10], indicating a dire need for novel therapeutics that are targeted, disease-, and age-specific.

Recently, mounting anecdotal reports and media coverage have sparked intense interest among parents, patients, and the scientific community regarding the potential of medical cannabis to treat seizures. A potential alternative or supplement to current AEDs, the cannabis plant includes $>100$ diverse phytocannabinoids that, in part, target an endogenous endocannabinoid signaling network, as well as other networks. Two major phytocannabinoids derived from cannabis are psychoactive $\Delta 9$ - tetrahydrocannabinol (THC) and nonpsychoactive cannabidiol (CBD). Both $\Delta 9$-THC and $\mathrm{CBD}$ can prevent seizures and reduce mortality in animal models of seizure with low toxicity and high tolerability [11]. However, a systematic analysis from the American Academy of Neurology and a Cochrane Database review both concluded that medical cannabis is of "unknown efficacy" to treat epilepsy $[12,13]$. In this review, we examine the history of cannabinoids in epilepsy, discuss the effectiveness of pre clinical seizure model studies with cannabinoids, and review recent clinical data, including a multicenter clinical trial of CBD for patients with treatment-resistant epilepsy.

\section{History of Cannabis in Epilepsy}

Cannabis has been used for millennia for medical, recreational, and manufacturing purposes. Around $2900 \mathrm{BCE}$, the Chinese Emperor Fu Hsi characterized cannabis as having sacred yin (weak, passive forces) and yang (strong, active forces) features, suggesting that it could restore homeostasis to an unbalanced body. Physicians in ancient India, Egypt, Persia, Rome, Arabia, and Greece used cannabis for spiritual and medicinal purposes, including menstrual fatigue, gout, rheumatism, malaria, beriberi, constipation, pain, and absentmindedness [14]. Early documented uses of cannabis to treat seizures include a Sumerian text from $2900 \mathrm{BCE}$ and an Arabian document from the twelfth century $[15,16]$.

The 1854, the US Dispensatory listed cannabis to treat neuralgia, depression, pain, muscle spasms, insomnia, tetanus, chorea, insanity, and other disorders [17]. Cannabis was valued for its analgesic, anti-inflammatory, appetite-stimulating, and antibiotic properties. In the mid-1800s, the British surgeon William O'Shaughnessy reported cannabis therapy for the treatment of epilepsy, recounting an "alleviation of pain in most, a remarkable increase of appetite in all, unequivocal aphrodisia, and great mental cheerfulness" [14, 18]. Two of England's most prominent mid-to-late nineteenth- century neurologists, J.R. Reynolds and W. Gowers, also noted the benefits of cannabis in epilepsy [19]. Gowers reported a man who previously failed bromides whose seizures were controlled on $9.8 \mathrm{~g}$ of Cannabis indica, dosed 3 times daily for up to 6 months [20].

Cannabis was first regulated in the USA with the 1906 "Pure Food and Drug Act". The follow-up 1937 Marijuana Tax Act was opposed by the American Medical Association, which considered the more severe restrictions an infringement on physician's freedom to treat patients [17]. In 1970, the US Comprehensive Drug Abuse Prevention and Control Act categorized marijuana as a Schedule I drug with high potential for abuse and no accepted medicinal use. Legislation has been introduced to the US Senate to change marijuana to a Schedule II drug.

Over the last 50 years, the main chemical constituents of cannabis have been isolated and synthesized. $\triangle 9$-THC was isolated in 1964 and synthesized in 1971 [21, 22]. CBD was isolated in 1940 and synthesized in 1963 [23, 24]. The cannabinoid type $1\left(\mathrm{CB}_{1} \mathrm{R}\right)$ and type $2\left(\mathrm{CB}_{2} \mathrm{R}\right)$ receptors, which bind $\triangle 9$-THC, were cloned in the 1990s [25, 26], supporting an endogenous system for this principal cannabinoid's pharmacological activity.

\section{The Endocannabinoid System}

The discovery of the endocannabinoid system in the early 1990s revealed the neuronal mechanisms that underlie the psychoactive effects of $\triangle 9-T H C$ in cannabis. Initial studies demonstrated that brief postsynaptic depolarization reduced neurotransmitter release from excitatory terminals onto Purkinje cells in the cerebellum and inhibitory terminals onto pyramidal neurons in the hippocampus [27, 28]. This phenomenon was termed "depolarization-induced suppression of excitation/inhibition" (DSE and DSI, respectively). Postsynaptic depolarization was postulated to trigger the release of an undiscovered substance that transiently limited presynaptic neurotransmitter release. Along with the discovery of nitric oxide (NO), this paradigmshifting view suggested the concept of retrograde signaling in contrast to a primarily anterograde view of synaptic signaling. Application of a $\mathrm{CB}_{1} \mathrm{R}$ agonist (or antagonist) enhanced (or prevented) DSE and DSI, suggesting that it was mediated by an endogenous cannabinoid ligand [29-31]. These endocannabinoids were identified as the hydrophobic ligands $N$-arachidonoyl ethanolamide (anandamide) [32] and 2-arachidonoyl glycerol (2-AG) [33, 34].

Anandamide and 2-AG are synthesized from postsynaptic membrane phospholipid precursors and released in an activity-dependent, "on-demand" manner, unlike traditional vesicular neurotransmitters (Fig. 1). Depolarization of the postsynaptic cell or direct activation of metabotropic glutamate receptors increases levels of intracellular calcium, which trigger second messenger cascades that promote endocannabinoid synthesis [35-39]. Anandamide is synthesized via 


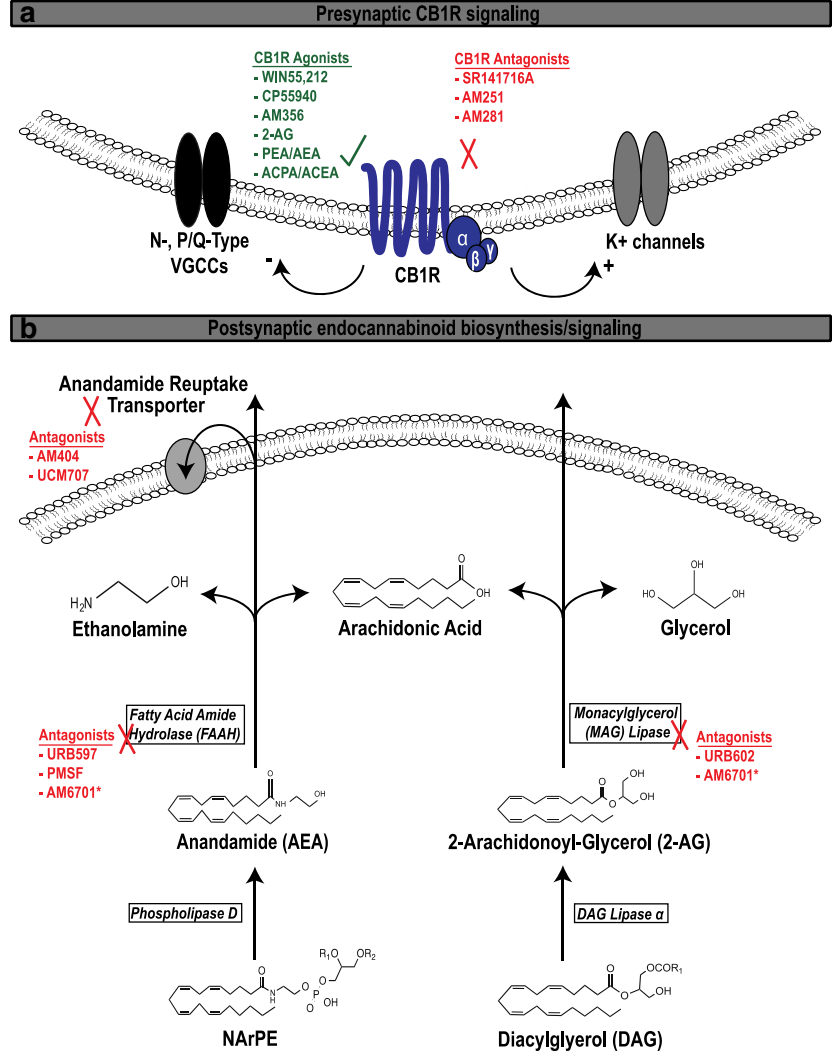

Fig. 1 Biosynthesis, degradation, and signaling of endocannabinoids. (A) Presynaptic cannabinoid type 1 receptor $\left(\mathrm{CB}_{1} \mathrm{R}\right)$ signaling. (B) Postsynaptic endocannabinoid biosynthesis/signaling. NArPE $=N$-arachidonoyl phosphatidylethanolamine; DAG = 1-acyl, 2-arachidonoyl diacylglycerol; VGCC $=$ voltage-gated calcium channels; PEA = palmitoylethanolamide; ACPA $=$ arachidonylcyclopropylamide; ACEA = arachidonyl-2'chloroethylamide; PMSF = phenylmethylsulfonyl fluoride

phospholipase D-mediated hydrolysis of $N$-arachidonoylphosphatidylethanolamine, and degraded by the fatty acid amide hydrolase (FAAH) into arachidonic acid and ethanolamine [40-43]. 2-AG is synthesized via diacylglycerol (DAG) lipase (DAGL) $\alpha$-mediated hydrolysis of DAG, and degraded by FAAH into arachidonic acid and glycerol, or by monoacylglycerol lipase [41-44]. Chronic hyperexcitability leads to dynamic changes in the endocannabinoid pathway (see "The Endocannabinoid System: $\mathrm{CB}_{1}$ Rs"). Thus, the enzymes that regulate metabolism and cannabinoid receptors represent attractive targets to treat several neurological disorders [45]. Accordingly, the selective $\mathrm{CB}_{1} \mathrm{R}$ blocker rimonabant was approved in $>50$ countries as an anorectic to treat obesity [46], and showed promise in helping smokers quit tobacco use [47], but its use was suspended when postmarketing surveillance revealed high rates of depression and suicidal ideation.

Produced in an activity-dependent manner, endocannabinoids travel to the presynaptic cell and bind to $\mathrm{CB}_{1}$ Rs. $\mathrm{CB}_{1} \mathrm{Rs}$ are $\mathrm{G}$ protein-coupled receptors linked to pertussis-sensitive Gi/o $\alpha$ subunits. Activation of the $\alpha$ subunit triggers dissociation of the $\beta \gamma$ complex, which reduces adenylate cyclase production of cyclic adenosine monophosphate [48], inhibits N- and P/Qtype voltage-gated calcium channels [31, 49-52], stimulates Atype potassium channels [53-56], activates $\mathrm{G}$ protein-coupled inwardly-rectifying potassium channels [57-59], and inhibits the vesicular release machinery [60]. These multiple mechanisms reduce presynaptic cell excitability and $\mathrm{Ca}^{2+}$, strongly diminishing presynaptic neurotransmitter release. $\mathrm{CB}_{1} \mathrm{Rs}$ can also regulate the presynaptic release of multiple neuromodulators such as acetylcholine, dopamine, and norepinephrine [61]. Finally, endocannabinoid signaling may modulate regional-specific long-term synaptic plasticity, including long-term potentiation and long-term depression (for a review, see [62, 63]).

$\mathrm{CB}_{1} \mathrm{Rs}$ are distributed primarily in axon terminals in the neocortex (especially cingulate, frontal, and parietal regions), hippocampus, amygdala, basal ganglia, thalamus, hypothalamus, nucleus accumbens, substantia nigra, ventral tegmental area, cerebellum, and brainstem [39]. $\mathrm{CB}_{1} \mathrm{Rs}$ are most densely expressed at cortical and hippocampal presynaptic $\gamma$-aminobutyric acid (GABA)ergic presynaptic boutons, especially cholecystokinin-positive $(\mathrm{CCK}+)$ and parvalbumin-negative GABAergic interneurons [64-66]. Glutamatergic axon terminals in cortical and subcortical neurons contain fewer presynaptic CB1 receptors than GABAergic terminals [65, 67-71].

\section{Phytocannabinoids: Classification and Function}

The cannabis plant consists contains $>100 \mathrm{C} 21$ terpenophenolic compounds, known collectively as phytocannabinoids [72]. Most of these lipophilic cannabinoids are closely related and differ only by a single chemical functional group. Cannabinoids fall into 10 main groups, with constituents representing degradation products, precursors, or byproducts (Fig. 2, adapted from [73]). Two of the most abundant constituents are $\Delta 9$-THC and $\mathrm{CBD}$, the ratios of which vary by cannabis strain. Cannabis sativa contains a higher ratio of $\triangle 9-\mathrm{THC}$ to $\mathrm{CBD}$, producing more stimulating, psychotropic effects. Cannabis indica strains contains a higher ratio of CBD: $\triangle 9-\mathrm{THC}$ and are typically more sedating $[11,73]$.

\section{$\Delta 9-$ THC}

$\triangle 9$-THC is a partial agonist at central nervous system (CNS) $\mathrm{CB}_{1}$ Rs and $\mathrm{CB}_{2} \mathrm{Rs}$ in the immune system. Most behavioral, cognitive, and psychotropic effects of cannabis result from the effects of $\Delta$ 9-THC at brain $\mathrm{CB}_{1}$ Rs. The subjective "high" produced by cannabis can be blocked by pretreatment with the $\mathrm{CB}_{1} \mathrm{R}$ antagonist rimonabant [74]. $\Delta 9$-THC impairs short-term working memory in several rodent models, which can be reversed by preapplication of a $\mathrm{CB}_{1} \mathrm{R}$ antagonist [75-78]. Inhibition of long-term potentiation at hippocampal CA3 Schaffer Collateral/CA1 synapses may underlie this 


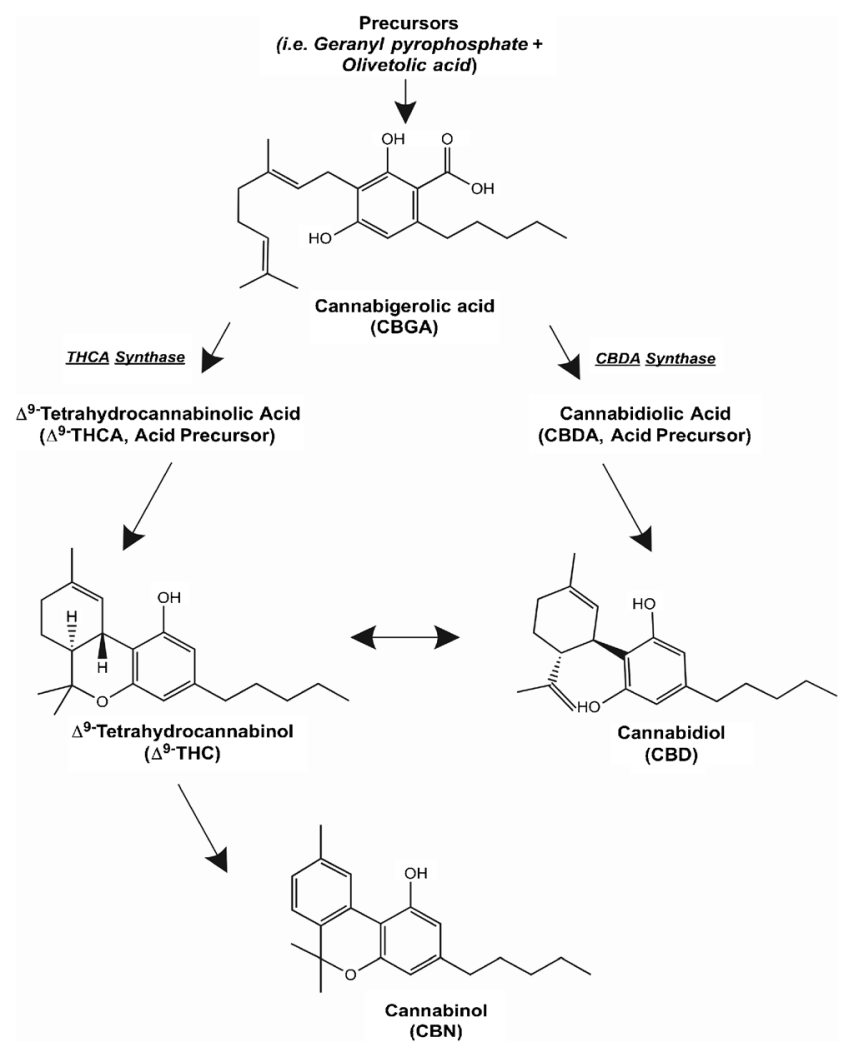

Fig. 2 Biosynthesis of phytocannabinoids [73]

effect on memory [35]. $\triangle 9$-THC or $\mathrm{CB}_{1} \mathrm{R}$ agonists can increase or decrease food intake in different species [79]. $\Delta 9$ THC also regulates neuronal excitability during seizures (see "Preclinical Evidence"). Thus, $\triangle 9$-THC acts through the endocannabinoid system to regulate mood, learning and memory, neuronal excitability, and energy balance. $\Delta 9-\mathrm{THC}$ exerts potent anti-inflammatory functions via $\mathrm{CB}_{1} \mathrm{Rs}$ and $\mathrm{CB}_{2} \mathrm{Rs}$ on microglia, the primary immune cells in the CNS. $\triangle 9$-THC or $\mathrm{CB}_{1} \mathrm{R}$ agonists limit neurotoxicity in in vitro and in vivo assays, including chemotoxic [80-83], low $\mathrm{Mg}^{2+}$ [84], and ischemic $[85,86]$ models. $\Delta 9$-THC has antioxidant effects in $\alpha$ amino-3-hydroxy-5-methyl-4-isoxazolepropionic acid- and $\mathrm{N}$-methyl-D-aspartate-mediated cytotoxicity models via a $\mathrm{CB}_{1} \mathrm{R}$-independent mechanism [87]. Cannabinoids reduce neuronal and glial release of the proinflammatory cytokines tumor necrosis factor- $\alpha$, NO, interleukin (IL)-1 and IL-6 [88-93], and increase release of anti-inflammatory cytokines IL-4, IL-10, and IL-1 receptor antagonist (IL-1a) [94, 95] via CB1R- and CB2R-dependent mechanisms in neurons and glia $[94,95]$ (reviewed in [96]). $\Delta 9-$ THC also transiently activates and desensitizes the transient receptor potential (TRP) channels TRPA1, TRPV1, and TRPV2 [97-99]. Given the synergistic relation between seizures and inflammation [100-102], the cannabinoid system provides a novel strategy to target both segments of this feedback cycle.

\section{CBD}

CBD resembles $\Delta 9$-THC structurally but the 2 molecules differ significantly in pharmacology and function. CBD has very low affinity at $\mathrm{CB}_{1} \mathrm{R}$ and $\mathrm{CB}_{2} \mathrm{R}$, unlike $\triangle 9$-THC [103-106]. The potential targets for CBD are reviewed in detail in another article in this issue ("Molecular Targets of CBD in Neurological Disorders"). CBD is an agonist at TRP channels (TRPV1, TRPV2, TRPA1) [98, 99, 104], 5hydroxytryptamine $1 \alpha$ receptors [107], and glycine receptors [108]. CBD is an antagonist at TRP melastatin type- 8 channels [97], T-type voltage-gated calcium channels [109], and G protein-coupled-receptor GPR55 (see below).

CBD exerts dynamic control over intracellular calcium stores through multiple, activity-dependent pathways [110, 111]. CBD induces a bidirectional change in intracellular calcium levels that depends on cellular excitability. Under normal physiological $\mathrm{Ca}^{2+}$ conditions, CBD slightly increases intracellular $\mathrm{Ca}^{2+}$, whereas $\mathrm{CBD}$ reduces intracellular $\mathrm{Ca}^{2+}$ under high-excitability conditions. These changes were blocked by the pretreatment with an antagonist of the mitochondrial $\mathrm{Na}^{+} /$ $\mathrm{Ca}^{2+}$ exchanger, suggesting a mitochondrial site of action [111]. CBD also produces biphasic changes in intracellular calcium levels via antagonism of the mitochondrial voltagedependent anion channel 1 [112].

CBD antagonizes GPR55, which functions as a counterpart to the canonical CB1R/CB2R signaling pathway [113]. GPR55 is present in the caudate, putamen, hippocampus, thalamus, pons, cerebellum, frontal cortex, and thalamus. GPR55 was initially characterized as a novel cannabinoid receptor, coupled to $\mathrm{G} \alpha 13$ [114]. Activation of GPR55 in human embryonic kidney cells triggers the release of intracellular $\mathrm{Ca}^{2+}$ from endoplasmic reticulum stores via a pathway dependent on RhoA (Ras homolog gene family member A), phospholipase $\mathrm{C}$, and inositol 1,4.5-trisphosphate receptor [115]. The endogenous membrane phospholipid L- $\alpha$ lysophosphatidylinositol is a GPR55 agonist [116]. Brief application of L- $\alpha$-lysophosphatidylinositol transiently increases intracellular $\mathrm{Ca}^{2+}$ levels and vesicular release probability at excitatory hippocampal synapses. CBD opposes this effect by reducing glutamate release, suggesting a potential antiseizure mechanism [117]. CBD also reduces epileptiform activity (burst amplitude and duration) in in vitro (4aminopyridine and $\mathrm{Mg}^{2+}$ ) models through a CB1-independent, concentration-dependent, and region-specific manner in the hippocampus. Preclinical studies demonstrate an antiseizure effect of CBD (see "Preclinical Evidence").

CBD also regulates several transporters, enzymes, and metabolic pathways that are common to $\triangle 9$-THC and endocannabinoid signaling. CBD inhibits uptake of adenosine by blocking the equilibrative nucleoside transporter [118, 119]. Increased levels of adenosine activate $A 2$ receptors, which regulate striatal $\mathrm{CB}_{1}$ Rs [120]. At high micromolar 
levels, CBD also inhibits the uptake and enzymatic degradation of anandamide via FAAH, elevating anandamide extracellular concentrations [121]. Thus, dynamic interactions likely occur between the multiple plant cannabinoids such as CBD and $\Delta 9$-THC (see "Entourage Effect").

CBD limits inflammation and oxidative stress [122]. CBD reduces oxidative toxicity in an in vitro glutamate excitotoxicity assay [123], and raises adenosine to oppose lipopolysaccharideinduced inflammation and tumor necrosis factor- $\alpha$ release [118, 124]. In mice with middle cerebral artery occlusion, CBD triggered a $\mathrm{CB}_{1} \mathrm{R}$-independent decrease in reperfusion injury, inflammation, and death. This neuroprotective action may result from reduced myeloperoxidase activity, neutrophil migration, and microglia high-mobility group box 1 expression [125, 126]. Additionally, CBD activates peroxisome proliferatoractivated receptor- $\gamma$, reduces NO and IL- $\beta$ release, limits gliosis, and restricts neuroinflammation in mice injected with amyloid $\beta$ [127-129]. Finally, treatment of microglial cultures with interferon- $\gamma$ raised mRNA levels of the CBD receptor GPR55 [130], which regulates the inflammatory responses to neuropathic pain [131]. Taken together, these studies suggest that CBD reduces neuroinflammation in several disease-specific conditions.

\section{The "Entourage Effect"}

The "entourage effect" was a term originally coined by BenShabat et al. [132] to refer to the potentiating effects of endocannabinoid metabolic byproducts on endocannabinoid function at $\mathrm{CB}_{1} \mathrm{Rs}$ and $\mathrm{CB}_{2} \mathrm{Rs}$. They observed that 2 esters of the endocannabinoid 2-AG-s2-linoleoyl-glycerol and 2palmitoyl-glycerol - were present in spleen, brain, and gut, together with 2-AG. While these esters do not bind to cannabinoid receptors or inhibit adenylyl cyclase via either $\mathrm{CB}_{1}$ or $\mathrm{CB}_{2}$, each ester potentiated 2-AG-induced inhibition of motor behavior, immobility on a ring, analgesia on a hot plate, and hypothermia: behavioral tests commonly referred to as the "tetrad' by which $\mathrm{CB}_{1}$-mediated effects can be detected [132]. Thus, the original concept of the entourage effect referred to a specific group of endogenous compounds, structurally similar to endocannabinoids, that potentiated the effects of endogenous cannabinoid receptor agonists at $\mathrm{CB}_{1} \mathrm{Rs}$ and $\mathrm{CB}_{2} \mathrm{Rs}$.

Subsequently, the idea of the entourage effect has expanded considerably both with regard to mechanisms of interactions, as well as classes of chemical agents. The diversification of entourage effects has been promoted by scientific and lay authors, and often well beyond its original boundaries. Wagner and Ulrich-Merzenich [133] proposed 4 potential mechanisms of synergy for phytotherapeutics, using cannabis as an exemplar: 1) multitarget effects; 2) pharmacokinetic effects (e.g., improved bioavailability or solubility); 3 ) improved bacterial resistance; and 4) modulation of adverse events (AEs; truly an antagonism, albeit a beneficial one) [133]. This approach thereby extended the tightly defined entourage effect to include practically any plant mixture acting through any molecular target to exert any effect.

The cannabis plant contains a complex mixture of both cannabinoids (i.e., $\triangle 9$-THC and CBD) and terpenoids (limonene, myrcene, $\alpha$-pinene, linalool, $\beta$-caryophyllene, caryophyllene oxide, nerolidol, and phytol) derived from a common precursor (geranyl pyrophosphate). Several studies posited that the "entourage" of "[whole] plants are better drugs than the natural products isolated from them", suggesting that the clinical effects of cannabis usage may be due to complex interactions between several plant cannabinoids [134, 135]. In support of this view, CBD may potentiate the beneficial effects associated with $\triangle 9$-THC (analgesia, antiemesis, and anti-inflammation) and reduce the negative psychoactive effects of $\Delta 9$-THC (impaired working memory, sedation, tachycardia, and paranoia) [136-138]. Users of cannabis with a high CBD: $\triangle 9$-THC ratio have greater tolerability and lower rates of psychosis than users of high $\Delta 9$-THC:CBD ratios (or $\Delta 9$-THC alone) [139]. Additional reports claim potential synergistic interactions of phytocannabinoids and phytoterpenoids that may include therapeutic effects on pain, inflammation, depression, anxiety, addiction, epilepsy, cancer, fungal, and bacterial infections $[135,140]$. However, proper characterization of any "synergistic" effects of multiple plant cannabinoids requires statistically robust demonstrations of effects greater than the sum of the parts. These effects can be tested in vitro or in vivo using assays such as the isobolographic approach $[141,142]$. Such a design can show if any 2 compounds, extracts, or mixtures are additive in the specific assay (e.g., models of seizure), synergistic, or antagonistic, thereby avoiding speculation about potential synergism or the confusion of additive effects with synergism. Although experimental data support the efficacy of both CBD and $\triangle 9$-THC as individual agents in various animal models of epilepsy, we are not aware of any studies demonstrating synergy of these compounds in animal models nor any controlled trials that establish a synergistic effect in patients with epilepsy.

Collectively, several studies demonstrate functional (but not defined molecular) interactions between plant cannabinoids that extended the initial concept of the entourage effect far beyond its original intent. While such interactions may exist, further well-defined research is required to verify anecdotal claims regarding the increased antiseizure efficacy of CBD with $\triangle 9$-THC (vs CBD alone) in patients with epilepsy. While natural selection may have led to combinations of phytochemicals in cannabis to resist infection or predation, there is no reason to expect "nature" to combine chemicals in a single plant to treat human epilepsy. 


\section{Animal Models of Seizures and Epilepsy}

Animal models provide powerful assays to assess the potential antiseizure or antiepileptic effects of cannabinoids. Each preclinical paradigm has unique advantages and disadvantages, and many represent unique seizure etiologies, semiologies, or corresponding electroencephalography (EEG) patterns. Table 1 (adapted from [143-145]) summarizes animal models discussed in this review, grouped by relevance to human epilepsies. Acute models (e.g., kainic acid and pentylenetetrazol) allow high-throughput screening for upregulation of biomarkers, but cannot recapitulate spontaneous recurrent seizures or reduced seizure thresholds found in chronic epilepsy. Chronic models of seizure activity elicit spontaneous, recurrent seizures that can be recorded on video EEG. While technically challenging, these models better represent epileptogenesis and drug screening for humans. However chronic models are specific to the type of insult (traumatic brain injury, mouse genetic models), and may not reflect broad anatomical or functional changes in generalized epilepsy [145].

\section{Preclinical Evidence of Cannabinoids in Epilepsy}

Multiple animal models demonstrate the efficacy of cannabinoids in preventing seizures and reducing mortality in epilepsy. Animal models highlight dynamic changes in the endocannabinoid system follow chronic seizures, with both acute and chronic homeostatic regulatory components.

\section{The Endocannabinoid System}

Endocannabinoid release prevents seizure-induced neurotoxicity. Kainic acid (KA) (30 mg/kg)-induced seizures increased levels of the anandamide in wild-type mice (20 min postinjection) [146], and pilocarpine (375 mg/kg)-induced seizures increased levels of 2-AG (15 min postseizure onset) [147]. Thus, epileptiform activity triggers a neuroprotective, on-demand release of endocannabinoids (or increase endocannabinoid levels in a downstream pathway unrelated to neuroprotection). Pretreatment with an anandamide reuptake inhibitor (UCM707; $3 \mathrm{mg} / \mathrm{kg}$ ) reduced KA-induced seizure severity, but not in mice with conditional CB1R deletion in principal forebrain excitatory neurons [146]. Blockade of the endocannabinoid catabolic enzyme FAAH (with AM374; $8 \mathrm{mg} / \mathrm{kg}$ ) increased levels of anandamide and protected against KA $(10 \mathrm{mg} / \mathrm{kg})$-induced hippocampal seizures and subsequent impairments in balance and coordination [148]. Inhibition of both FAAH (with AM374) and the anandamide reuptake transporter (with AM404) in rat hippocampus prevented $\alpha$-amino-3-hydroxy-5-methyl-4isoxazolepropionic acid-induced excitotoxic insults (cytoskeletal damage and synaptic decline) in vitro and behavioral and memory impairment in vivo [149]. Blockage of FAAH and DAGL $\alpha$ (with AM6701, $5 \mathrm{mg} / \mathrm{kg}$ ) raised levels of anandamide and 2-AG, protected against KA $(10 \mathrm{mg} / \mathrm{kg})$-induced seizures, and reduced seizure-induced cytotoxicity [150]. The endocannabinoids, methanandamide, and 2-AG reduced neuronal firing in a low $\mathrm{Mg}^{2+}$ in vitro model of status epilepticus, in a dose-dependent manner $\left(\mathrm{EC}_{50} 145 \pm 4.15 \mathrm{nM}\right.$ methanandamide, $1.68 \pm 0.19 \mu \mathrm{M} 2-\mathrm{AG})$ [151].

\section{$\mathrm{CB}_{1} \mathrm{Rs}$}

Animal models demonstrate that activation of $\mathrm{CB}_{1}$ Rs reduces seizure severity. Mice with conditional deletion of $\mathrm{CB}_{1} \mathrm{Rs}$ in principal forebrain excitatory neurons (but not interneurons) exhibited more severe KA-induced seizures $(30 \mathrm{mg} / \mathrm{kg}$ ) than wild-type controls. Conditional deletion of the $\mathrm{CB}_{1} \mathrm{R}$ increased gliosis and apoptosis following KA-induced seizures and prevented activation of the protective immediate early genes (c-Fos, Zif268, brain-derived neurotrophic factor) [146]. $\mathrm{CB}_{1} \mathrm{R}$ expression in hippocampal glutamatergic (but not GABAergic) inputs is necessary and sufficient to protect against KA-induced seizures [152]. Further, viral-induced overexpression of $\mathrm{CB}_{1} \mathrm{Rs}$ targeted to the hippocampus reduced KA-induced seizure severity, seizure-induced CA3 pyramidal cell death, and mortality [153], Together, these results demonstrate that $\mathrm{CB}_{1} \mathrm{Rs}$ could limit seizure activity and protect neurons from subsequent cell death and reactive gliosis.

Seizures trigger homeostatic changes in hippocampal $\mathrm{CB}_{1} \mathrm{Rs}$ and the endocannabinoid system (reviewed in [154]) (Fig. 3). Levels of $\mathrm{CB}_{1} \mathrm{R}$ expression in the CA1-3 stratum oriens and radiatum (presumed excitatory inputs) and dentate gyrus steadily increased 1-week post-pilocarpine-induced seizures (Fig. 3, dark green trace) [147, 155-158]. However, sclerotic and nonsclerotic hippocampal tissue resected from patients with epilepsy displayed a reduction in DAGL $\alpha$ (2AG biosynthetic enzyme), $\mathrm{CB}_{1} \mathrm{R}$ mRNA, and $\mathrm{CB}_{1} \mathrm{R}$ excitatory terminal immunoreactivity (Fig. 3, light green trace) [159]. Furthermore, compared with healthy controls, patients with temporal lobe epilepsy have reduced levels of anandamide in cerebrospinal fluid samples [160]. These findings suggest that seizure activity induces a homeostatic upregulation of excitatory terminal $\mathrm{CB}_{1} \mathrm{Rs}$, which may reduce excitatory neurotransmitter release via DSE (see "The Endocannabinoid System"). This compensatory process may be impaired in patients with prolonged treatment-resistant epilepsy or hippocampal sclerosis, leading to neuronal hyperexcitability, pharmacoresistance, and inconsistent effects of cannabis exposure. However, further research is required to verify the functional effects of this potential process in human patients, and whether $\mathrm{CB}_{1} \mathrm{R}$ homeostasis indeed limits seizure severity or occurrence.

In contrast to effects at excitatory terminals, seizures induce a homeostatic reduction in $\mathrm{CB}_{1} \mathrm{R}$ expression in inhibitory 


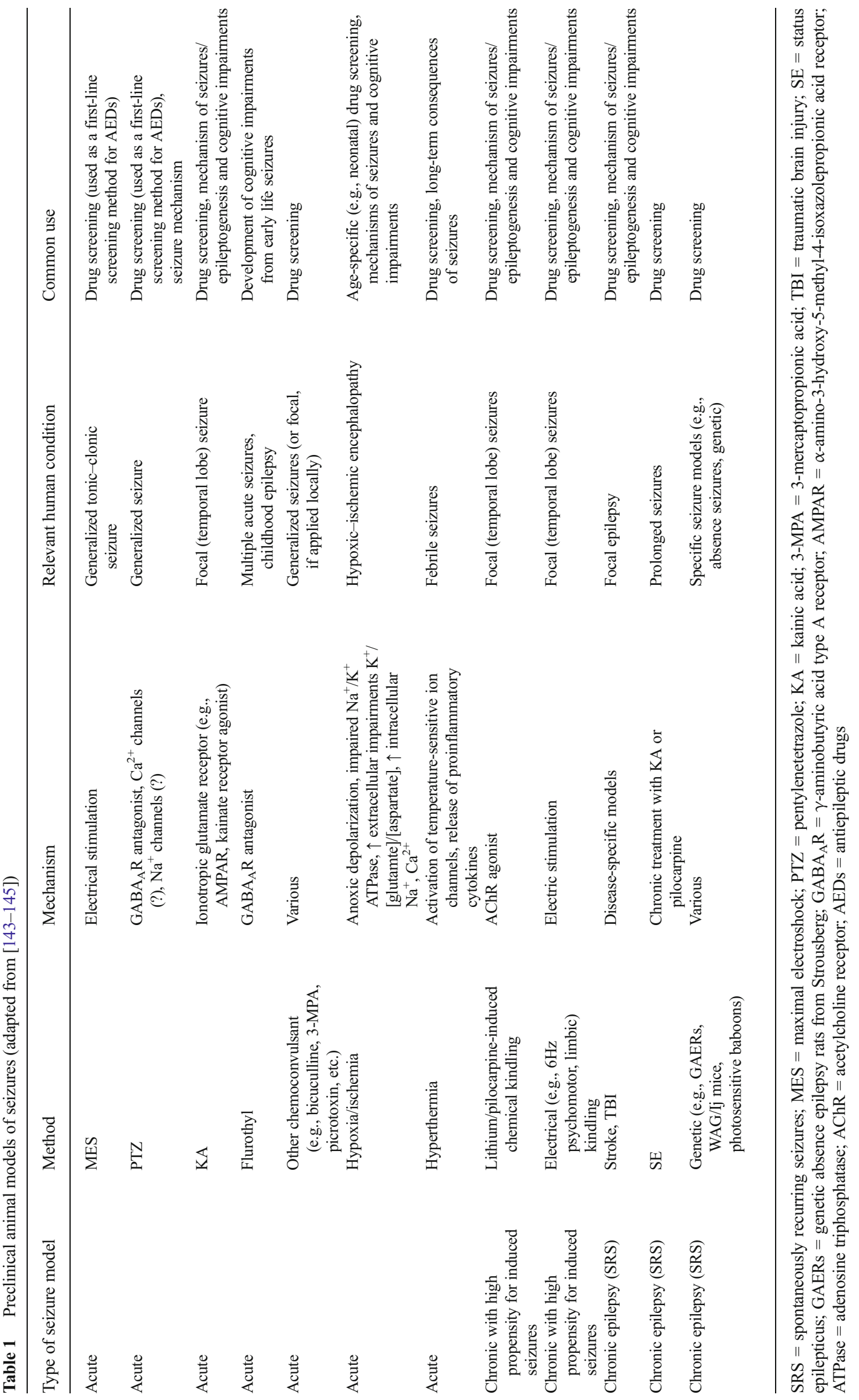


terminals (Fig. 3, dark red trace). Beginning 4 days following pilocarpine-induced seizures in rats, $\mathrm{CB}_{1} \mathrm{R}$ expression progressively decreased in hippocampal $\mathrm{CCK}+$ inhibitory nerve terminals [161], particularly in the CA1 stratum pyramidale and the dentate gyrus inner molecular layer, unaccounted for by CA1 neuronal cell loss alone $[155,156,162]$. By reducing $\mathrm{CB}_{1} \mathrm{R}$ expression on inhibitory terminals (and presumed DSI), this homoeostatic process may limit network disinhibtion and restrain elevated excitability during prolonged epileptiform activity. In sclerotic hippocampal tissue removed from 1) 2 months post pilocarpine-induced seizures in mice [163], and 2) human patients [164], levels of $\mathrm{CB}_{1}$ Rs remained consistently elevated in interneuron axonal terminals (Fig. 3, light red trace). This finding suggests that patients with prolonged, pharmacoresistant epilepsy may suffer from impaired $\mathrm{CB}_{1} \mathrm{R}$ homeostasis on inhibitory interneuron terminals, leading to prolonged disinhibition and network excitability. Postseizure changes in $\mathrm{CB}_{1} \mathrm{Rs}$ may be specific to seizure type or developmental stage, as mice with a single episode of febrile seizures induce an overall increase in DSI and $\mathrm{CB}_{1} \mathrm{R}$ on $\mathrm{CCK}+$ interneurons $[165,166]$.

\section{Modulators of the Endocannabinoid System and Synthetic $\mathrm{CB}_{1} \mathrm{R}$ Agonists/Antagonists}

Figure 4 summarizes the effects of synthetic cannabinoids and phytocannabinoids in 175 pre-clinical seizure models or discrete conditions (adapted from [167]). These studies are subclassified by drug type and seizure model in corresponding tables in the Appendix (see Supplementary Material).

Results from 13 studies from 3 species (rat, mouse, guinea pig) demonstrate that modulation of the endocannabinoid system (via inhibition of FAAH or anandamide reuptake) provides about $46.2 \%(6 / 13)$ anticonvulsant, $23.1 \%(3 / 13)$ mixed effect, and $30.8 \%(4 / 13)$ no significant effect in seizure models. $\mathrm{CB}_{1} \mathrm{R}$ agonists produced an anticonvulsant effect in $68.1 \%(47 / 69)$, proconvulsant effect in $2.9 \%(2 / 69)$, mixed effect in $7.2 \%(5 / 69)$, and no significant effect in $21.7 \%(15 /$ $69)$ of seizure models in rats and mice. One study suggests that
$\mathrm{CB}_{1} \mathrm{R}$ agonists may produce an anticonvulsant effect through $\mathrm{CB}_{1} \mathrm{Rs}$ at low doses, but a proconvulsive effect through TRPV1 channels at high doses [168]. In addition, $\mathrm{CB}_{1} \mathrm{R}$ agonists (WIN55, 212, ACEA) often produce a additive effect when combined with several commonly prescribed AEDs (see Fig. 4B) [169-177]. In 18 studies from mice, rats, and guinea pigs, $\mathrm{CB}_{1} \mathrm{R}$ antagonists were pro convulsant in $38.9 \%$ (7/18), anti-convulsant in 5.6\% (1/18), and showed no significant effect in $55.6 \%(10 / 18)$ of trials. Although $\mathrm{CB}_{1} \mathrm{R}$ agonists were anticonvulsant in $68.1 \%$ of the studies, only $38.9 \%$ of $\mathrm{CB}_{1} \mathrm{R}$ antagonists were proconvulsive (most showed no effect). Thus, while activation of the endocannabinoid system may prevent long-term consequences of seizure sequelae, inhibition of the endogenous protective mechanisms may not contribute significantly to seizures. Variations in the pro- $v$ anticonvulsant effects in each system may reflect specific effects of the species, seizure models (acute vs chronic, focal vs generalized), dose ranges, timing, or experimental design.

\section{Phytocannabinoids: $\triangle 9$-THC and CBD}

Evidence from 34 studies from 6 animal species demonstrate that $\triangle 9$-THC is anticonvulsant in $61.8 \%(21 / 34)$, proconvulsant in $2.9 \%(1 / 34)$, mixed in $2.9 \%(1 / 34)$, and shows no significant effect in $32.4 \%(11 / 34)$ of seizure models. $\triangle 9$-THC potentiated the effects of phenytoin and phenobarbital in the maximal electroshock model of generalized seizures [178, 179]. The National Toxicology Program noted a pro convulsant effect of $\triangle 9$-THC in rats and mice [180], although species-specific differences in $\mathrm{CB}_{1} \mathrm{R}$ expression may underlie variable responses to $\triangle 9-\mathrm{THC}$. CBD and its homologue cannabidivarin (CBDV) were $80.5 \%(33 / 41)$ anticonvulsive and $19.5 \%$ (8/41) ineffective, at reducing seizures in mice and rats. Notably, no studies showed a proconvulsive effect for $\mathrm{CBD}$ or $\mathrm{CBDV}$. CBDV potentiated the effects of phenobarbital, ethosuximide, and valproate in 2 seizure models [181]. These studies suggest that both $\Delta 9$ THC and CBD provide significant protection from seizures
Fig. 3 Homeostatic changes to hippocampal cannabinoid type 1 receptors $\left(\mathrm{CB}_{1} \mathrm{Rs}\right)$ in preclinical animal seizure models [147, 154-166]. GABA $=\gamma-$ aminobutryic acid
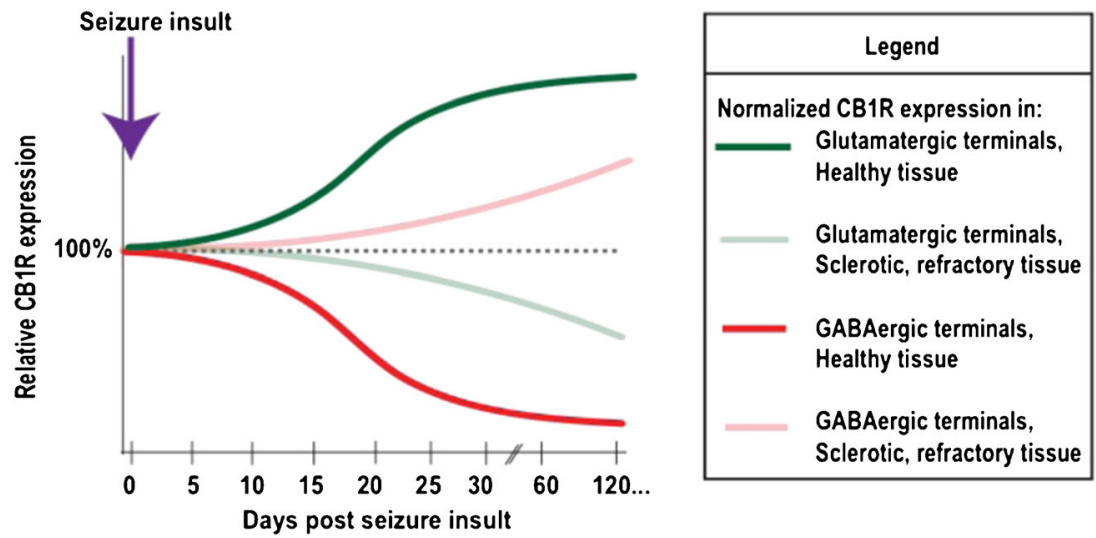
in preclinical animal trials, presenting potential targets for human studies.

\section{Tolerance and Withdrawal}

Prolonged treatment with $\triangle 9-\mathrm{THC}$ or synthetic $\mathrm{CB} 1$ agonists leads to a dose-dependent and region-specific desensitization, downregulation, and internalization of $\mathrm{CB}_{1} \mathrm{Rs}$ [182-203]. These changes produce tolerance to the acute behavioral effects of $\triangle 9$-THC in in vivo models, reducing cannabinoidinduced hypomotility, hypothermia, antinocioception, and memory impairment with repeated usage $[182,183,185$, 197, 199, 204, 205]. In several seizure models, prolonged $\triangle 9$-THC (but not CBD) exposure leads to tolerance to the antiepileptic activity of cannabinoids [206-210]. In humans, chronic cannabinoid usage produces tolerance towards $\Delta 9$ THC-mediated changes in autonomic behaviors, sleep and sleep EEGs, and self-reported psychotropic high, although these changes vary in frequent users [211-216].

Withdrawal from rats chronically dosed with $\triangle 9$-THC triggers rebound seizures and elevated anxiety-like responses in several preclinical animal studies [217-219]. Monkeys that previously self-administered intravenous $\Delta 9$-THC demonstrate abstinent symptoms of aggressiveness, hyperirritability, and anorexia [220], as well as impaired operant behavior [221]. Results from human studies demonstrated symptoms of anxiety, aggression, dysphoria, irritability, anorexia, sleep disturbances, and sweating during abstinence from chronic $\Delta 9$-THC usage, rescued by $\Delta 9$-THC re-administration [222]. Withdrawal from cannabis use can trigger rebound seizures in several preclinical animal and human studies [203, $209,210,223-226]$, although other studies show no proconvulsant effect of cannabis withdrawal [178, 227].

Unlike $\Delta 9$-THC, CBD (or nabiximols, $\mathrm{CBD} / \Delta 9-\mathrm{THC}$ in a 1:1 ratio) does not seem to produce significant intoxication [228], tolerance [229-231], or withdrawal effects [232]. CBD and/or nabiximols may counteract the $\triangle 9$-THC-dominant effects of cannabis withdrawal [233-235]. In summary, evidence suggests that while both tolerance and some withdrawal symptoms may occur with $\triangle 9$-THC, CBD may limit the effects of cannabis tolerance and withdrawal, but more studies are needed.

\section{Clinical Evidence of Cannabinoids in Epilepsy}

Several clinical studies have examined the association between cannabis use and seizures. These include case studies, surveys and epidemiological studies, and clinical trials.

\section{Case Studies}

Case reports describe proconvulsant and anticonvulsant effect of cannabis, with the majority reporting either beneficial or lack of effect on seizure control. Selected examples illustrate the diverse spectrum of reported responses. Cannabis used 7 times within 3 weeks was associated with multiple tonic-clonic seizures in a patient previously seizure free for 6 months on phenytoin and phenobarbital. However, seizures were not temporally correlated with immediate intoxication or withdrawal [236]. Cannabis withdrawal increased complex partial seizure frequency in a 29-year-old man with a history of alcoholism and bipolar disorder (each of with are independently associated with seizures) [226]. In another 2-part case study, a 43-year-old on carbamazepine experienced about 5-6 nightly violent seizures lasting $1 \mathrm{~min}$ each. When he consumed about $40 \mathrm{mg}$ C. sativa at night, seizure frequency was reduced by $70 \%$, but withdrawal triggered a doubling of his baseline seizure frequency. In the same study, a 60-year-old man with a 40-year history of cannabis usage (6-8 cigarettes per day) developed status epilepticus after cannabis withdrawal [225]. Additionally, synthetic "designer" cannabinoid drugs ("spice" or "K2") induce new-onset seizures, tacharrythmia, and psychosis, often with greater severity and toxicity than cannabis [237-245]. The toxicity of these synthetic agents may result from their properties as full agonists of $\mathrm{CB}_{1} \mathrm{R}$, while $\Delta 9$-THC is a partial agonist.

The majority of other studies demonstrate an anticonvulsant effect of cannabis. In a 1949 trial, administration of a $\Delta 9$ THC homolog (1,2-dimethyl heptyl) reduced the "severe anticonvulsant resistant (phenobarbital or phenytoin) grand mal epilepsy" in $2 / 5$ children [246]. One patient whose seizures were not controlled on low-dose phenobarbital or phenytoin had fewer tonic-clonic seizures while smoking 2-5 cannabis cigarettes per day [247]. Myoclonic and other seizures were reportedly reduced in 3 adolescents on oral $0.07-0.14 \mathrm{mg} / \mathrm{kg}$ $\triangle 9$-THC daily. Parents reported that their children were "more relaxed...more alert, more interested in her surroundings" [248]. In another study, a 45-year-old man with cerebral palsy and treatment-resistant focal epilepsy experienced a marked reduction in focal and secondary generalized seizures on daily marijuana [249]. Other recent cases also support the observation that cannabis use can reduce seizures in some patients $[250,251]$. These studies suggest that cannabis can not only reduce seizure susceptibility, but also trigger rebound seizures during withdrawal. Limitations of open-label, often retrospective single case reports are compounded by the variability in epilepsy syndrome, differences in cannabis dosage, route, and composition.

\section{Epidemiological Reports and Surveys}

Recent epidemiological reports and surveys depict the incidence of medical marijuana usage for seizure control. The predicted prevalence of medical cannabis use in epileptic patients ranges from about $4 \%$ ( $77=$ total patient population in US medical cannabis program) to about $20 \%(310=$ total patients at a tertiary 


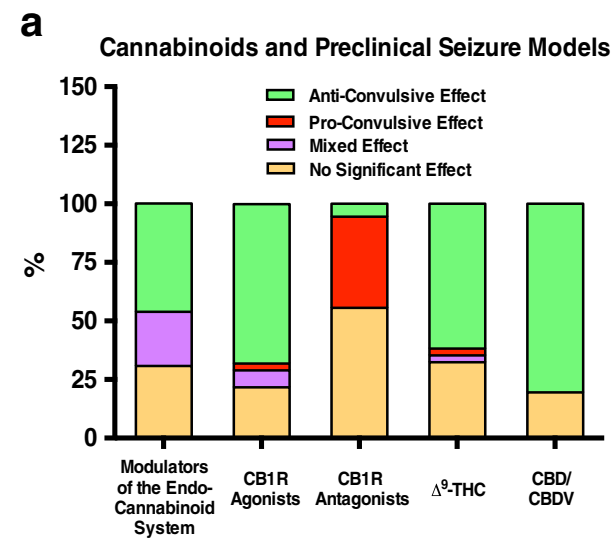

\begin{tabular}{|c|c|c|c|c|c|}
\hline & $\begin{array}{c}\text { Modulators of } \\
\text { the Endo- } \\
\text { cannabinoid } \\
\text { System }\end{array}$ & $\begin{array}{c}\text { CB1R } \\
\text { Agonists }\end{array}$ & $\begin{array}{c}\text { CB1R } \\
\text { Antagonists }\end{array}$ & $\Delta^{9}$-THC & $\begin{array}{c}\text { CBD/ } \\
\text { CBDV }\end{array}$ \\
\hline \# of Species & 3 & 2 & 3 & 6 & 2 \\
\hline $\begin{array}{c}\text { \# of Discrete } \\
\text { Conditions/ } \\
\text { Models }\end{array}$ & 13 & 69 & 18 & 34 & 41 \\
\hline $\begin{array}{c}\text { Anti- } \\
\text { convulsant }\end{array}$ & $\begin{array}{c}6 \\
(46.2 \%)\end{array}$ & $\begin{array}{c}47 \\
(68.1 \%)\end{array}$ & $\begin{array}{c}1 \\
(5.6 \%)\end{array}$ & $\begin{array}{c}21 \\
(61.8 \%)\end{array}$ & $\begin{array}{c}33 \\
(80.5 \%)\end{array}$ \\
\hline $\begin{array}{c}\text { Pro- } \\
\text { convulsant }\end{array}$ & 0 & 2 & 7 & 1 & 0 \\
\hline $\begin{array}{c}\text { Mixed Effect } \\
(0 \%)\end{array}$ & $\begin{array}{c}2.9 \%) \\
(23.1 \%)\end{array}$ & $\begin{array}{c}5 \\
(7.2 \%)\end{array}$ & $\begin{array}{c}0 \\
(0 \%)\end{array}$ & $\begin{array}{c}1 \\
(2.9 \%)\end{array}$ & $\begin{array}{c}0 \\
(0 \%)\end{array}$ \\
\hline $\begin{array}{c}\text { No } \\
\text { Significant } \\
\text { Effect }\end{array}$ & $(30.8 \%)$ & $(21.7 \%)$ & $(55.6 \%)$ & $\begin{array}{c}11 \\
(32.4 \%)\end{array}$ & $\begin{array}{c}8 \\
(19.5 \%)\end{array}$ \\
\hline
\end{tabular}

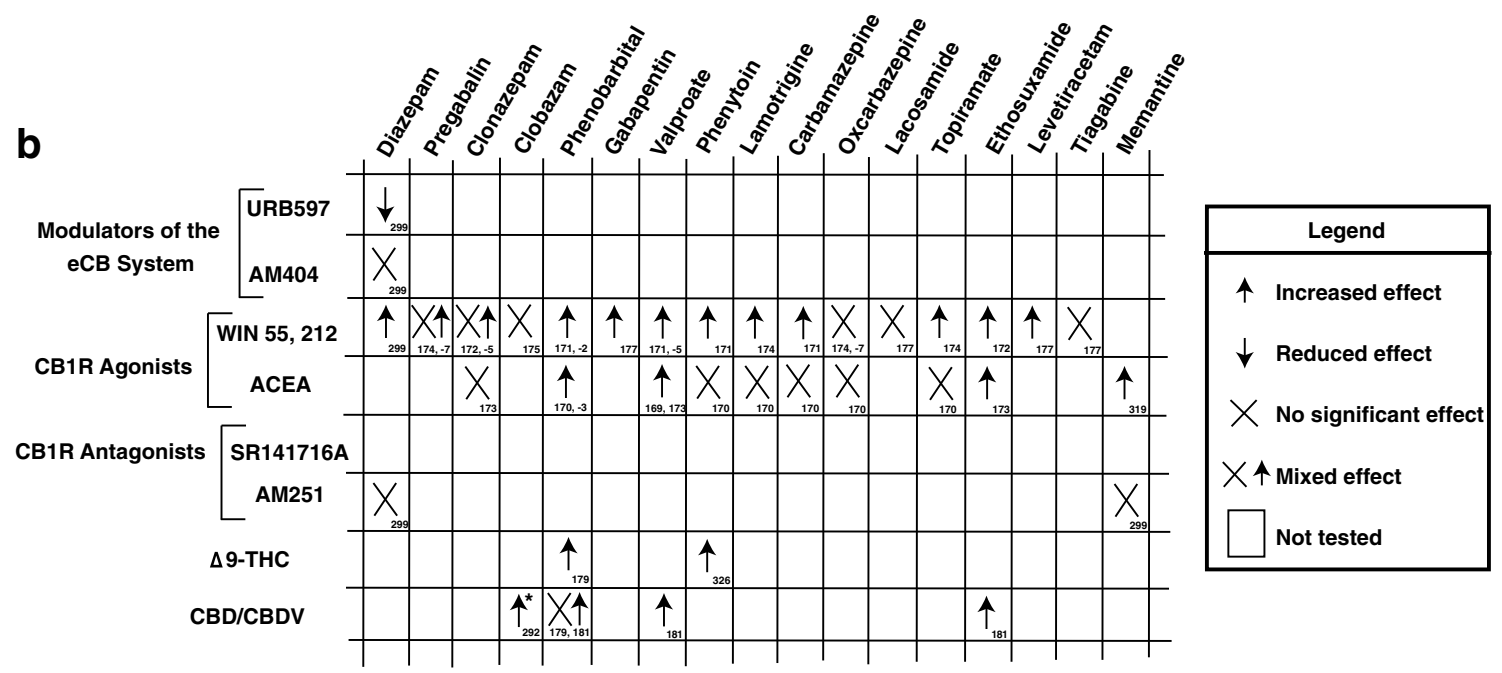

Fig. 4 Summary of cannabinoids and preclinical seizure models. (A) Composite data from 175 preclinical seizure models (e.g., maximal electroshock, kainic acid) or discrete experimental designs (e.g., with combined antiseizure medications). Pro-/antiseizure effects are subclassified by given intervention: 1) modulators of the endocannabinoid (eCB) system (e.g., fatty acid amide hydrolase inhibitor URB597); 2) cannabinoid type 1 receptor $\left(\mathrm{CB}_{1} \mathrm{R}\right)$ agonists (e.g., WIN55212-2); 3) $\mathrm{CB}_{1} \mathrm{R}$ antagonists (e.g., SR141716A); 4) $\Delta^{9}$ - tetrahydrocannabinol ( $\left.\Delta^{9}-\mathrm{THC}\right)$; and 5) cannabidiol (CBD)/ cannabidivarin (CBDV). (See Supplementary Material for complete description of preclinical studies.) (B) Summary of preclinical data on cannabinoid interactions with antiseizure medications. Sources indicated in boxes. ${ }^{*}$ Recent evidence from a phase I clinical trial suggests that $\mathrm{CBD} / \mathrm{CBDV}$ elevates serum concentrations of clobazam and $\mathrm{N}$-desmethylclobazam in human pediatric patients with treatmentresistant epilepsy [292]. ACEA = arachidonyl-2'-chloroethylamide epilepsy clinic in Germany) $[252,253]$. One percent of the medical marijuana users in California $(\sim 2500=$ total patient population) use cannabis to control seizures [254]. In a telephone survey of 136 patients with epilepsy, $21.0 \%$ were active users, $13.0 \%$ were frequent users, $8.1 \%$ were heavy users, and $3.0 \%$ met Diagnostic and Statistical Manual of Mental Disorders-IV criteria for marijuana dependence.

The majority of patient and caregiver surveys found either beneficial effects or no significant effect of cannabis in patients with epilepsy. In a small, 1976 survey of 300 patients with epilepsy, cannabis usage had no effect on seizure frequency in $30 \%$ of patients, increased seizures in 1 patient, and decreased seizures in another [255]. A 1989 12-year retrospective study reported $10 \%$ of 47 patients with "recreational drug-induced [tonic-clonic] seizures" had consumed cannabis prior to seizures, although this was confounded by recent cocaine, amphetamine, or LSD (lysergic acid diethylamide) usage. No seizures were reported following cannabis use alone [256]. A single epidemiological study provided limited evidence that cannabis may possess antiseizure properties in humans. In a study of illicit drug use and new-onset seizures in Harlem utilizing a case-control methodology, cannabis used within 90 days before hospitalization was associated with a 2.8 -fold decreased risk of first seizures among men but not women [257]. In a telephone survey of adult patients from a tertiary care epilepsy center, most active users reported beneficial effects on seizures (68\% reduced severity, $54 \%$ reduced incidence), and $24 \%$ of all subjects believed marijuana was an effective therapy for epilepsy. No patient reported a worsening of seizures with cannabis use [258]. The majority (84\%) of patients in a German tertiary care center reported that cannabis had no effect on their seizure control [253]. 
A 2013 survey of 19 parents of children with treatmentresistant epilepsy investigated the use of high CBD: $\triangle 9$-THC ratio artisanal marijuana products. These parents were primarily identified from social media and included 12 children with Dravet syndrome (DS). Of the 12 children with DS, parents reported that $5(42 \%)$ experienced a $>80 \%$ reduction in seizure frequency and $2(11 \%)$ reported complete seizure freedom. The single child with Lennox-Gastaut syndrome (LGS) was reported to have a $>80 \%$ reduction in seizure frequency. In addition to seizure control, parents reported positive effects of increased alertness (74\%), better mood (79\%), improved sleep (68\%), and decreased self-stimulation (32\%), and rare AEs of drowsiness $(37 \%)$ and fatigue $(16 \%)$ [259]. A more recent retrospective case study described 75 patients from Colorado with treatment-resistant epilepsy who moved to Colorado for oral cannabis extract treatment. Oral cannabis extract treatment controlled seizures in $57 \%$ of patients, reduced seizures by $>50 \%$ in $33 \%$ of patients, and showed greater effectiveness in patients with LGS (88.9 \%) than in patients with DS (23.0 \%). Reported additional benefits included improved behavior/alertness (33\%), language (10\%), and motor skills (10\%), as well as rare AEs of increased seizures (13\%) and somnolence/fatigue (12\%). Interestingly, the study also reported a significant, independent "placebo effect" of families moving to Colorado for treatment (see "Placebo Effect") [260]. Collectively, these surveys suggest a predominantly antiseizure (or no significant) effect of cannabis usage. However, it is essential to consider the limitations of subjective self-reporting, potentially biased sampling of patient advocacy groups (over-reporting positive effects), and uncontrolled differences in CBD: $\triangle 9$-THC content in various strains of cannabis in these studies.

\section{Clinical Trials}

A recent Cochrane review assessed 4 primary clinical trials to examine the efficacy of medical marijuana in seizure control (summarized in Table 2, adapted from [11], [13]). Two of these studies demonstrated a partial antiseizure effect of CBD [261, 262], while 2 showed no significant effect [263, 264]. However, all 4 studies included significant limitations, including low study sizes, insufficient blinding or randomization, or incomplete data sets. The authors of the Cochrane review and a recent meta-analysis from the American Academy of Neurology both emphasized the need for follow-up placebo-controlled, blinded, randomized clinical trials examining the role of CBD in seizure control $[12,13]$.

\section{Phase I Clinical Trial for CBD in Treatment-resistant Epilepsy}

Preliminary preclinical and clinical evidence reveal the therapeutic potential of CBD to reduce seizures with high tolerability and low toxicity. Accordingly, CBD represents a highly desirable treatment alternative for patients with earlyonset, severe epilepsy such as DS and LGS. In addition to pharmacoresistant seizures, these patients suffer from severe neurodevelopmental delay, intellectual disability, autism, motor impairments, and significant morbidity and mortality [265, 266]. As patients with DS and LGS require effective and better-tolerated therapies and represent relatively homogeneous populations, they stand out as candidates for an initial trial of CBD safety and efficacy.

\section{Study Design and Results}

Investigator-initiated open-label studies at 10 epilepsy centers using Epidiolex (GWPharma, Salisbury, UK; 99 \% CBD) collected data on 213 patients with treatment-resistant epilepsies. This predominantly pediatric population had a mean age of 10.8 years (range $2.0-26.0$ years). CBD was added to existing AEDs; there was an average of 3 concomitant AEDs. The average baseline was 60 per month for total seizures and 30 per month for convulsive seizures.

The primary goal of the study was to assess safety but seizure diaries were obtained for convulsive, drop, and total seizures to provide a potential signal regarding efficacy. Twelve-week or longer continuous exposure data were obtained for 137 patients and were used in efficacy measures. The most common epilepsy etiologies were DS and LGS syndromes; others included Aicardi syndrome, Doose syndrome, tuberous sclerosis complex, CDKL5, Dup15q syndrome, and many others. At week 12, total convulsive and nonconvulsive seizures showed a median percent reduction from baseline of $54 \%$, and total convulsive seizures showed a median percent reduction from baseline of $51 \%$. In patients with DS $(n=23)$, CBD reduced convulsive seizure frequency by $53 \%$, and $16 \%$ of DS reached complete convulsive seizure freedom by week 12. Atonic seizure frequency among patients with LGS $(n=10)$ was reduced by a median of $52 \%$ at week 12 . AEs $>10 \%$ included somnolence $(21 \%)$, diarrhea (17\%), fatigue (17\%), and decreased appetite (16\%). Nine patients (4\%) were discontinued for AEs. The investigators concluded that CBD reduced seizure frequency across multiple drugresistant epilepsy syndromes and seizure types and was generally well-tolerated in the open-label study. Randomized controlled trials (RCTs) are now ongoing for DS and LGS.

\section{Safety Issues}

There is a strong tendency to equate "cannabis as a natural therapy" with "cannabis as a safe therapy". This a priori assumption - the naturalistic fallacy - is countered by many instances of toxic or deadly plants (e.g., amotoxins in mushrooms) and animals (e.g., tetrodotoxin in puffer fish). A more muted naturalistic view is that if side effects occur with 
cannabis, they would be less severe than those from drugs produced by the pharmaceutical industry. A recent Epilepsia survey of 776 individuals found that $98 \%$ of the general public supported the use of medical marijuana for severe cases of epilepsy, compared with only $48 \%$ of epileptologists. Similarly, the majority of the public and a minority of epileptologists thought that there was sufficient safety $(96 \%$ vs $34 \%$ ) and efficacy ( $95 \%$ vs $28 \%$ ) data for medical marijuana use in severe epilepsy. This significant disparity in opinion between professionals and the lay public, possibly swayed by the appeal of natural remedies, emphasizes an increased need for further research and public education regarding medicinal cannabis and epilepsy [267].

As with efficacy, the most valid assessment of side effects is with RCTs. RCT data on the safety of $\triangle 9-T H C$ and CBD in adults comes from trials of cannabinoid-containing medications, including nabixomols [Sativex (GWPharma) 1:1 $\Delta 9$ THC:CBD], purified cannabis extracts [Cannador, Institute for Clinical Research, IKF, Berlin, Germany, (2:1 $\Delta$ 9-THC:CBD)], synthetic $\triangle 9$-THC analogues Dronabinol and Nabilone. These drugs have been approved by many international regulatory agencies. In a meta-analysis of 1619 patients treated with nabiximols for neurological indications (mainly pain, spasticity, spasm, or tremor) for 6 months or less, $6.9 \%$ of those on cannabinoid therapies were discontinued because of adverse effects versus $2.25 \%$ in the placebo groups [12]. Adverse effects occurring in at least 2 studies included nausea, dizziness, increased weakness, behavioral or mood changes, hallucinations, suicidal ideation, fatigue, and feeling of intoxication. No deaths from overdose were reported [12]. However, our knowledge on the safety of these compounds in children is very limited.

The adverse health effects of recreational cannabis use were recently reviewed [268]. $\Delta 9-\mathrm{THC}$ is presumed to be the major cannabinoid resulting in adverse acute and chronic health effects of cannabis. The 4-fold increase in $\triangle 9$-THC content of confiscated cannabis in the last 20 years is associated with increased acute complications. In 2011, there were 129,000 emergency department visits for cannabis alone and 327,000 additional visits for cannabis in combination with other drugs. From 2004 to 2011, the rate of emergency department visits for cannabis toxicity doubled [268]. Short-term use can impair short-term memory, coordination, and judgment. In high doses, paranoia and psychosis can occur [137, 269]. Long-term use of recreational cannabis in adolescents is associated with addiction $(9 \%$ overall but $17 \%$ among adolescents) and impaired cognitive and academic performance [270-274]. Additionally, cannabis treatment in animal and human studies altered brain development (especially with use in early childhood) and structure [272, 275-277], creating long-lasting functional and structural brain abnormalities [277-279]. Early and/or heavy cannabis use is associated with neurochemical abnormalities on magnetic resonance spectroscopy [272], impaired maintenance of neuronal cytoskeleton dynamics [277], decreased white matter development or integrity
[272, 275, 276], increased impulsivity [276], and abnormal activation patterns during cognitive tasks on functional magnetic resonance imaging $[272,280]$. In patients with multiple sclerosis, use of cannabis is associated with impaired cognition and activation patterns on functional magnetic resonance imaging [281]. Further research is required to determine the short- and long-term effects of CBD alone, which may have lower toxicity than whole plant cannabis or $\Delta 9$-THC.

\section{Cannabidiol Formulations, Pharmacokinetics, Pharmacodynamics, and Drug-Drug Interactions}

We are aware of 3 pharmaceutical products that are currently in trials or in development: 1) Epidiolex (99 \% CBD derived from C. sativa plants, in a strawberry-flavored sesame oil), 2) synthetic CBD from Insys Therapeutics (Chandler, AZ, USA), and 3) Transdermal CBD gel from Zynerba Pharmaceuticals (Devon, PA, USA). Other CBD-containing products are available commercially and obtained online [e.g., Realm of Caring's Charlotte's Web (whole cannabis extract containing $50 \mathrm{mg} / \mathrm{ml} \mathrm{CBD}$ )]. However, the quality control and consistency of these products may vary considerably. Indeed, a recent study by the US Food and Drug Administration tested 18 products, claimed to contain CBD, made by 6 companies. Of these, 8 contained no CBD, 9 contained $<1 \%$ CBD, and 1 contained $2.6 \%$ CBD (http://www.fda.gov/NewsEvents/ PublicHealthFocus/ucm435591.htm).

Because lipophilic cannabinoids (including CBD) have low water solubility, CBD is traditionally delivered orally in either an oil-based capsule or sublingual spray, permitting less variable pharmacokinetics in gastrointestinal absorption. A single 10-mg dose of nabiximols (equal parts CBD and $\triangle 9$-THC) in humans produces a maximum serum concentration $\left(\mathrm{C}_{\max }\right)$ of $3.0 \pm 3.1 \mu \mathrm{g} / \mathrm{l}$ (buccal) $[2.5 \pm 1.8 \mu \mathrm{g} / \mathrm{l}$ (sublingual)] and maximum time $\left(\mathrm{T}_{\max }\right)$ of $2.8 \pm 1.3 \mathrm{~h}$ (buccal) $[1.6 \pm 0.7 \mathrm{~h}$ (sublingual)] [282]. CBD is primarily protein-bound in the blood, and preferentially deposits in brain and adipose tissue [283].

The cannabinoids are primarily metabolized by the liver cytochrome P-450 (CYP-450) enzymes. Both $\Delta 9$-THC and CBD can inhibit CYP-450 metabolic activity, particularly the CYP2C isozymes at low concentrations and CYP3A4 isozymes at higher concentrations [284-289]. CYP2C and CYP3A4 are induced by carbamazepine, topiramate, and phenytoin, and inhibited valproate and other drugs [290]. The cannabinoids, particularly CBD, can inhibit other isozymes, including 2D6 and 1A1 [285, 291]. Therefore, use of $\Delta 9$ THC or CBD could potentially contribute to bidirectional drug-drug interactions with antiepileptic and other drugs. In our open-label CBD study, patients treated with CBD had elevated levels of the nordesmethyl metabolite of clobazam [292], which may account for a portion of the apparent sedation, as well as efficacy, of CBD. 


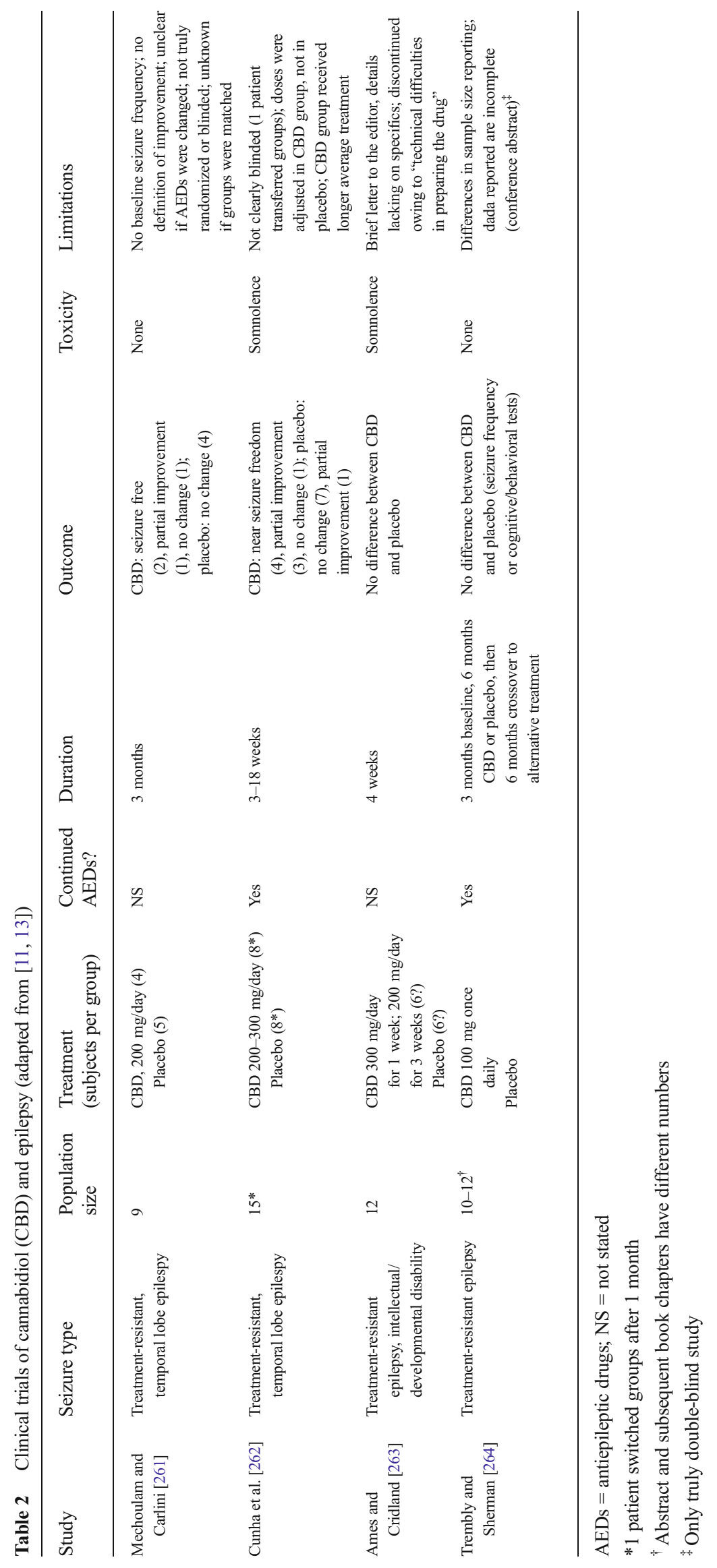




\section{Placebo Effect}

The magnitude of the placebo response is related to the power of belief. Given the social and mainstream media attention selectively reporting dramatic benefits of artisanal cannabis preparations for children with epilepsy, there are high expectations on the part of many parents. The potent role of the placebo response was suggested by a recent survey of parents whose children with epilepsy who were cared for at Colorado Children's Hospital. A beneficial response ( $>50 \%$ seizure reduction) was reported 3 times more often by parents who moved to the state compared with those who were long-time residents [260]. No differences in epilepsy syndrome, type of artisanal preparation, or other factor could account for this difference.

While studies have reported a significant placebo response in adult patients (such as those with Parkinson's Disease [293]), placebo response rates are particularly high among children and adolescents in a subset of disorders, including psychiatric (anxiety, major depression, and obsessive compulsive and attention deficit disorders), medical (asthma), and painful (migraine, gastrointestinal) conditions [294, 295]. As the current RCTs of CBD primarily target children with severe epilepsy, this may be an important issue. Among patients with treatment-resistant focal epilepsy, a meta-analysis found that the placebo response in children (19.9\%) was significantly higher than in adults $(9.9 \%$ ), while the response to the AED was not statistically different in children (37.2\%) and adults (30.4\%) [296]. In one predominantly pediatric LGS trial, seizures were reduced in $63 \%$ of placebo-treated patients and $75 \%$ of drug-treated patients [297]. Paradoxically, the intense interest and strong beliefs in the efficacy of cannabis for epilepsy may elevate placebo responses and make it more difficult to demonstrate a true benefit in RCTs.

\section{Legal/Ethical Concerns}

The Drug Enforcement Agency (DEA) classifies cannabis and products derived from cannabis plants as Schedule I drugs. Schedule I drugs have a high potential for abuse and no currently accepted medical use; they are the most dangerous drugs of all the drug schedules with potentially severe psychological or physical dependence (DEA website; http://www. dea.gov/druginfo/ds.shtml). It is thus paradoxical that opiates and benzodiazepines, which have a much greater potential for psychological and physical dependence than cannabis, are classified as Schedule II drugs. With regard to the DEA's "claim" that cannabis-derived drugs have no currently accepted medical use, therapies such as nabiximols (CBD and $\Delta 9$ THC) and other products have been approved by regulatory agencies in $>20$ countries. These approvals are based on RCTs that establish efficacy and a favorable safety profile, including a low potential for abuse $[228,298]$.
The Schedule I categorization makes it challenging for investigators to study cannabis-derived cannabinoids in basic and clinical science. There is often a long and costly process to secure approvals and inspections to obtain cannabinoids, purchase a large safe, the weight of which may require clearance from engineers, and add security systems to the room and building in which they are stored. The Schedule I designation often prevents patients who live in developmental centers or residential homes from participating in clinical trials. The threshold of effort for basic and clinical investigators to study cannabinoids remains as high as ever, while the availability of these substances for parents to give is expanding rapidly. This has created a widening gap between knowledge and exposure, an especially relevant concern in children for whom safety data are largely lacking.

\section{Conclusion}

For over a millennium, pre-clinical and clinical evidence have shown that cannabinoids such as CBD can be used to reduce seizures effectively, particularly in patients with treatmentresistant epilepsy. However, many questions still remain (see Box 1) regarding the mechanism, safety, and efficacy of cannabinoids in short- and long-term use. Future basic science research and planned multicenter, placebo-controlled clinical trials will provide insight into cannabinoid function and the potential neuroprotective effects of the endocannabinoid system. These findings will increase our mechanistic understanding of seizures and may provide novel, targeted therapeutics for epilepsy.

Box 1 Unanswered questions and directions for future studies

1. How do the pro and anti-epileptic effects of cannabis change with development? Are there age-specific differences in responsiveness, side effects, and target receptor expression?

2. What are the long-term effects of cannabis/cannabidiol use?

3. Are certain types of seizures or genetic channelopathies more likely to respond to cannabidiol than others?

4. What is the safety of cannabidiol in patients with special conditions (pregnancy, recent or planned surgery, vagus nerve stimulation, etc.)?

5. How do synthetic cannabinoids ("spice" or "K2") dysregulate the central nervous system to induce seizures? What is their relative safety and toxicity relative to cannabis?

Acknowledgments Drs. Orrin Devinsky and Ben Whalley have received research support from GW Pharmaceuticals. We acknowledge FACES (Finding a Cure for Epilepsy and Seizures) for generous help in the preparation of this manuscript. R.W.T. is supported by grants from the National Institute of Mental Health (5R37MH071739) and the National Institute of Neurological Disorders and Stroke (5R01NS074785, 5R01NS024067). 


\section{References}

1. Fisher RS, et al. Epileptic seizures and epilepsy: definitions proposed by the International League Against Epilepsy (ILAE) and the International Bureau for Epilepsy (IBE). Epilepsia 2005;46: 470-472.

2. Kwan P, Brodie MJ. Early identification of refractory epilepsy. N Engl J Med 2000;342:314-319.

3. Kwan P, Brodie MJ. Refractory epilepsy: a progressive, intractable but preventable condition? Seizure 2002;11:77-84.

4. Kwan P, Schachter SC, Brodie MJ. Drug-resistant epilepsy. N Engl J Med 2011; 365:919-926.

5. Nilsson L, et al. Risk factors for sudden unexpected death in epilepsy: a case-control study. Lancet 1999;353:888-893.

6. Walczak TS, et al. Incidence and risk factors in sudden unexpected death in epilepsy: a prospective cohort study. Neurology 2001;56: 519-525.

7. Devinsky O. Patients with refractory seizures. N Engl J Med 1999;340:1565-1570.

8. Jacoby A, Baker GA. Quality-of-life trajectories in epilepsy: a review of the literature. Epilepsy Behav 2008;12:557-571.

9. Rogawski MA. The intrinsic severity hypothesis of pharmacoresistance to antiepileptic drugs. Epilepsia 2013;54(Suppl. 2):33-40.

10. Perucca E. Is there a role for therapeutic drug monitoring of new anticonvulsants? Clin Pharmacokinet 2000;38:191-204.

11. Devinsky O, et al. Cannabidiol: pharmacology and potential therapeutic role in epilepsy and other neuropsychiatric disorders. Epilepsia 2014;55:791-802.

12. Koppel BS, et al. Systematic review: efficacy and safety of medical marijuana in selected neurologic disorders: report of the Guideline Development Subcommittee of the American Academy of Neurology. Neurology 2014;82:1556-63.

13. Gloss D, Vickrey B. Cannabinoids for epilepsy. Cochrane Database Syst Rev 2014; 3:CD009270.

14. Abel EL. Marihuana: the first twelve thousand years. Plenum Press, New York, 1980.

15. Russo EB, et al. Phytochemical and genetic analyses of ancient cannabis from Central Asia. J Exp Bot 2008;59:4171-4182.

16. Lozano I. The therapeutic use of Cannabis sativa L. in Arabic medicine. J Cannabis Ther 2001;1:63-70.

17. Szaflarski JP, Bebin EM. Cannabis, cannabidiol, and epilepsyfrom receptors to clinical response. Epilepsy Behav 2014;41:277282

18. O'Shaughnessy WB. On the preparations of the Indian hemp, or Gunjah. Prov Med J Retrosp Med Sci 1843;5:363-369.

19. Reynolds JR. Epilepsy: its symptoms, treatment, and relation to other chronic convulsive diseases. J. Churchill (Ed.) London, 1861.

20. Gowers W. Epilepsy and other chronic convulsive disorders. Churchill (Ed.) London, 1881.

21. Gaoni Y, Mechoulam R. Isolation, structure, and partial synthesis of an active constituent of hashish. J Am Chem Soc 1964;86: 1646-1647.

22. Gaoni Y, Mechoulam R. The isolation and structure of delta-1tetrahydrocannabinol and other neutral cannabinoids from hashish. J Am Chem Soc 1971;9:217-224.

23. Adams R, Pease DC, Clark JH. Isolation of cannabinol, cannabidiol, and quebrachitrol from red oil of Minnesota wild hemp. J Am Chem Soc 1940;62: 2194-2196.

24. Michoulam R, Shvo Y., Hashish, I. The structure of cannabidiol. Tetrahedron 1963; 19:2073-2078.

25. Matsuda LA, et al. Structure of a cannabinoid receptor and functional expression of the cloned cDNA. Nature 1990;346:561-564.
26. Munro S, Thomas KL, Abu-Shaar M. Molecular characterization of a peripheral receptor for cannabinoids. Nature 1993;365:61-65.

27. Llano I, et al. Synaptic- and agonist-induced excitatory currents of Purkinje cells in rat cerebellar slices. J Physiol 1991;434:183-213.

28. Pitler TA, Alger BE. Postsynaptic spike firing reduces synaptic $\mathrm{GABA}_{\mathrm{A}}$ responses in hippocampal pyramidal cells. J Neurosci 1992;12:4122-4132.

29. Kreitzer AC, Regehr WG. Retrograde inhibition of presynaptic calcium influx by endogenous cannabinoids at excitatory synapses onto Purkinje cells. Neuron 2001;29:717-727.

30. Kreitzer AC, Regehr WG. Cerebellar depolarization-induced suppression of inhibition is mediated by endogenous cannabinoids. J Neurosci 2001;21:RC174.

31. Wilson RI, Kunos G, Nicoll RA. Presynaptic specificity of endocannabinoid signaling in the hippocampus. Neuron 2001;31:453-462.

32. Devane WA, et al. Isolation and structure of a brain constituent that binds to the cannabinoid receptor. Science 1992;258:19461949.

33. Mechoulam R, et al. Identification of an endogenous 2-monoglyceride, present in canine gut, that binds to cannabinoid receptors. Biochem Pharmacol 1995;50:83-90.

34. Sugiura T, et al. 2-Arachidonoylglycerol: a possible endogenous cannabinoid receptor ligand in brain. Biochem Biophys Res Commun 1995;215:89-97.

35. Alger BE. Retrograde signaling in the regulation of synaptic transmission: focus on endocannabinoids. Prog Neurobiol 2002;68: 247-286.

36. Brown SP, Brenowitz SD, Regehr WG. Brief presynaptic bursts evoke synapse-specific retrograde inhibition mediated by endogenous cannabinoids. Nat Neurosci 2003;6:1048-1057.

37. Maejima T, Ohno-Shosaku T, Kano M. Endogenous cannabinoid as a retrograde messenger from depolarized postsynaptic neurons to presynaptic terminals. Neurosci Res 2001;40:205-210.

38. Melis M, et al. Prefrontal cortex stimulation induces 2arachidonoyl-glycerol-mediated suppression of excitation in dopamine neurons. J Neurosci 2004;24:10707-10715.

39. Katona I, Freund TF. Endocannabinoid signaling as a synaptic circuit breaker in neurological disease. Nat Med 2008;14:923-930.

40. Di Marzo V, et al. Formation and inactivation of endogenous cannabinoid anandamide in central neurons. Nature 1994;372:686691.

41. Di Marzo V, Deutsch DG. Biochemistry of the endogenous ligands of cannabinoid receptors. Neurobiol Dis 1998;5:386-404.

42. Di Marzo V, et al. Endocannabinoids: endogenous cannabinoid receptor ligands with neuromodulatory action. Trends Neurosci 1998;21:521-528.

43. Sugiura $\mathrm{T}$, et al. Biosynthesis and degradation of anandamide and 2-arachidonoylglycerol and their possible physiological significance. Prostaglandins Leukot Essent Fatty Acids 2002;66:173192.

44. Stella N, Schweitzer P, Piomelli D. A second endogenous cannabinoid that modulates long-term potentiation. Nature 1997;388: 773-778.

45. Pertwee RG. Cannabinoid receptor ligands: clinical and neuropharmacological considerations, relevant to future drug discovery and development. Expert Opin Investig Drugs 2000;9:1553-1571.

46. Pi-Sunyer F, et al. Effect of rimonabant, a cannabinoid-1 receptor blocker, on weight and cardiometabolic risk factors in overweight or obese patients - RIO-North America: A randomized controlled trial. JAMA 2006;295:761-775.

47. Cahill K, Ussher M. Cannabinoid type 1 receptor antagonists (rimonabant) for smoking cessation. Cochrane Database Syst Rev 2007:CD005353.

48. Glass M.. Felder CC. Concurrent stimulation of cannabinoid CB1 and dopamine D2 receptors augments cAMP accumulation in 
striatal neurons: evidence for a Gs linkage to the CB1 receptor. J Neurosci 1997; 17:5327-5333.

49. Mackie K, Hille B. Cannabinoids inhibit N-type calcium channels in neuroblastoma-glioma cells. Proc Natl Acad Sci U S A 1992;89:3825-3829.

50. Caulfield MP, Brown DA. Cannabinoid receptor agonists inhibit Ca current in NG108-15 neuroblastoma cells via a pertussis toxinsensitive mechanism. Br J Pharmacol 1992;106:231-232.

51. Twitchell W, Brown S, Mackie K. Cannabinoids inhibit N- and $\mathrm{P} / \mathrm{Q}-$ type calcium channels in cultured rat hippocampal neurons. J Neurophysiol 1997;78:43-50.

52. Szabo GG, et al. Presynaptic calcium channel inhibition underlies $\mathrm{CB}$ (1) cannabinoid receptor-mediated suppression of GABA release. J Neurosci 2014;34:7958-7963.

53. Deadwyler SA, et al. Cannabinoids modulate potassium current in cultured hippocampal neurons. Receptors Channels 1993;1:121134.

54. Deadwyler SA, et al. Cannabinoids modulate voltage sensitive potassium A-current in hippocampal neurons via a cAMPdependent process. J Pharmacol Exp Ther 1995;273:734-743.

55. Hampson RE, et al. Role of cyclic AMP dependent protein kinase in cannabinoid receptor modulation of potassium "A-current" in cultured rat hippocampal neurons. Life Sci 1995;56:2081-2088.

56. $\mathrm{Mu}$ J, et al. Protein kinase-dependent phosphorylation and cannabinoid receptor modulation of potassium A current (IA) in cultured rat hippocampal neurons. Pflugers Arch 2000;439:541-546.

57. Henry DJ, Chavkin C. Activation of inwardly rectifying potassium channels (GIRK1) by co-expressed rat brain cannabinoid receptors in Xenopus oocytes. Neurosci Lett 1995;186:91-94.

58. Mackie K, et al. Cannabinoids activate an inwardly rectifying potassium conductance and inhibit Q-type calcium currents in AtT20 cells transfected with rat brain cannabinoid receptor. J Neurosci 1995; 15:6552-6561.

59. McAllister SD, et al. Cannabinoid receptors can activate and inhibit $\mathrm{G}$ protein-coupled inwardly rectifying potassium channels in a xenopus oocyte expression system. J Pharmacol Exp Ther 1999;291:618-626.

60. Photowala $\mathrm{H}$, et al. $\mathrm{G}$ protein betagamma-subunits activated by serotonin mediate presynaptic inhibition by regulating vesicle fusion properties. Proc Natl Acad Sci U S A 2006;103:4281-4286.

61. Schlicker E, Kathmann M. Modulation of transmitter release via presynaptic cannabinoid receptors. Trends Pharmacol Sci 2001;22:565-572.

62. Chevaleyre V, Takahashi KA, Castillo PE. Endocannabinoidmediated synaptic plasticity in the CNS. Annu Rev Neurosci 2006;29:37-76.

63. Piomelli D. The molecular logic of endocannabinoid signalling. Nat Rev Neurosci 2003;4:873-884.

64. Katona I, et al. Presynaptically located CB1 cannabinoid receptors regulate GABA release from axon terminals of specific hippocampal interneurons. J Neurosci 1999; 19:4544-4558.

65. Marsicano G, Lutz B. Expression of the cannabinoid receptor CB1 in distinct neuronal subpopulations in the adult mouse forebrain. Eur J Neurosci 1999;11: 4213-4225.

66. Dudok B, et al. Cell-specific STORM super-resolution imaging reveals nanoscale organization of cannabinoid signaling. Nat Neurosci 2015;18:75-86.

67. Kawamura Y, et al. The CB1 cannabinoid receptor is the major cannabinoid receptor at excitatory presynaptic sites in the hippocampus and cerebellum. J Neurosci 2006;26:2991-3001.

68. Katona I, et al. Molecular composition of the endocannabinoid system at glutamatergic synapses. J Neurosci 2006;26:5628-5637.

69. Lafourcade $\mathrm{M}$, et al. Molecular components and functions of the endocannabinoid system in mouse prefrontal cortex. PLoS One 2007;2:e709.
70. Wittmann G, et al. Distribution of type 1 cannabinoid receptor (CB1)-immunoreactive axons in the mouse hypothalamus. J Comp Neurol 2007;503:270-279.

71. Robbe D, et al. Localization and mechanisms of action of cannabinoid receptors at the glutamatergic synapses of the mouse nucleus accumbens. J Neurosci 2001;21:109-116.

72. Elsohly MA, Slade D. Chemical constituents of marijuana: the complex mixture of natural cannabinoids. Life Sci 2005;78:539548.

73. Joy JE. Marijuana and medicine: assessing the science base. National Academics Press, Washington, DC 1999.

74. Huestis MA, et al. Blockade of effects of smoked marijuana by the CB1-selective cannabinoid receptor antagonist SR141716. Arch Gen Psychiatry 2001;58:322-328.

75. Lichtman AH, Martin BR. Delta 9-tetrahydrocannabinol impairs spatial memory through a cannabinoid receptor mechanism. Psychopharmacology (Berl) 1996;126: 125-131.

76. Mallet PE, Beninger RJ. The cannabinoid CB1 receptor antagonist SR141716A attenuates the memory impairment produced by delta9-tetrahydrocannabinol or anandamide. Psychopharmacology (Berl) 1998;140:11-19.

77. Varvel SA, et al. Differential effects of delta 9-THC on spatial reference and working memory in mice. Psychopharmacology (Berl) 2001;157:142-150.

78. Da S, Takahashi RN. SR 141716A prevents delta 9tetrahydrocannabinol-induced spatial learning deficit in a Morris-type water maze in mice. Prog Neuropsychopharmacol Biol Psychiatry 2002;26:321-325.

79. Pagotto U, et al. The emerging role of the endocannabinoid system in endocrine regulation and energy balance. Endocr Rev 2006;27: $73-100$.

80. Abood ME, et al. Activation of the CB1 cannabinoid receptor protects cultured mouse spinal neurons against excitotoxicity. Neurosci Lett 2001;309:197-201.

81. van der Stelt M, et al. Neuroprotection by Delta9-tetrahydrocannabinol, the main active compound in marijuana, against ouabaininduced in vivo excitotoxicity. J Neurosci 2001;21:6475-6479.

82. El-Remessy AB, et al. Neuroprotective effect of (-)Delta9-tetrahydrocannabinol and cannabidiol in N-methyl-D-aspartate-induced retinal neurotoxicity: involvement of peroxynitrite. Am J Pathol 2003;163:1997-2008.

83. Mechoulam R, Panikashvili D, Shohami E. Cannabinoids and brain injury: therapeutic implications. Trends Mol Med 2002;8: 58-61.

84. Gilbert GL, et al. Delta9-tetrahydrocannabinol protects hippocampal neurons from excitotoxicity. Brain Res 2007;1128:61-69.

85. Nagayama T, et al. Cannabinoids and neuroprotection in global and focal cerebral ischemia and in neuronal cultures. J Neurosci 1999;19:2987-2995.

86. Zani A, et al. Delta9-tetrahydrocannabinol (THC) and AM 404 protect against cerebral ischaemia in gerbils through a mechanism involving cannabinoid and opioid receptors. Br J Pharmacol 2007;152:1301-1311.

87. Hampson AJ, et al. Cannabidiol and (-)Delta9-tetrahydrocannabinol are neuroprotective antioxidants. Proc Natl Acad Sci U S A 1998;95:8268-8273.

88. Molina-Holgado F, Lledo A, Guaza C. Anandamide suppresses nitric oxide and TNF-alpha responses to Theiler's virus or endotoxin in astrocytes. Neuroreport 1997;8:1929-1933.

89. Molina-Holgado F, et al. Role of CB1 and CB2 receptors in the inhibitory effects of cannabinoids on lipopolysaccharide-induced nitric oxide release in astrocyte cultures. J Neurosci Res 2002;67: 829-836.

90. Shohami E, et al. Cytokine production in the brain following closed head injury: dexanabinol (HU-211) is a novel TNF-alpha 
inhibitor and an effective neuroprotectant. J Neuroimmunol 1997;72:169-177.

91. Puffenbarger RA, Boothe AC, Cabral GA. Cannabinoids inhibit LPS-inducible cytokine mRNA expression in rat microglial cells. Glia 2000;29:58-69.

92. Cabral GA, Harmon KN, Carlisle SJ. Cannabinoid-mediated inhibition of inducible nitric oxide production by rat microglial cells: evidence for CB1 receptor participation. Adv Exp Med Biol 2001;493:207-214.

93. Ehrhart J, et al. Stimulation of cannabinoid receptor 2 (CB2) suppresses microglial activation. J Neuroinflammation 2005;2:29.

94. Klein TW, et al. The cannabinoid system and cytokine network. Proc Soc Exp Biol Med 2000;225:1-8.

95. Molina-Holgado F, et al. Endogenous interleukin-1 receptor antagonist mediates anti-inflammatory and neuroprotective actions of cannabinoids in neurons and glia. J Neurosci 2003;23:64706474.

96. Benito $\mathrm{C}$, et al. Cannabinoid $\mathrm{CB} 2$ receptors in human brain inflammation. Br J Pharmacol 2008;153:277-285.

97. De Petrocellis L, et al. Plant-derived cannabinoids modulate the activity of transient receptor potential channels of ankyrin type-1 and melastatin type-8. J Pharmacol Exp Ther 2008;325:10071015.

98. De Petrocellis L, et al. Effects of cannabinoids and cannabinoidenriched Cannabis extracts on TRP channels and endocannabinoid metabolic enzymes. Br J Pharmacol 2011;163: 1479-1494.

99. Qin N, et al. TRPV2 is activated by cannabidiol and mediates CGRP release in cultured rat dorsal root ganglion neurons. J Neurosci 2008;28:6231-6238.

100. Vezzani A, et al. The role of inflammation in epilepsy. Nat Rev Neurol 2011;7:31-40.

101. Walker L, Sills GJ. Inflammation and epilepsy: the foundations for a new therapeutic approach in epilepsy? Epilepsy Curr 2012;12:812.

102. Devinsky O, et al. Glia and epilepsy: excitability and inflammation. Trends Neurosci 2013;36:174-184.

103. Thomas BF, et al. Comparative receptor binding analyses of cannabinoid agonists and antagonists. J Pharmacol Exp Ther 1998;285:285-292.

104. Bisogno T, et al. Molecular targets for cannabidiol and its synthetic analogues: effect on vanilloid VR1 receptors and on the cellular uptake and enzymatic hydrolysis of anandamide. Br J Pharmacol 2001;134:845-852.

105. Pertwee RG. GPR55: a new member of the cannabinoid receptor clan? Br J Pharmacol 2007;152:984-986.

106. Jones NA, et al. Cannabidiol displays antiepileptiform and antiseizure properties in vitro and in vivo. J Pharmacol Exp Ther 2010;332:569-577.

107. Russo EB, et al. Agonistic properties of cannabidiol at 5-HT1a receptors. Neurochem Res 2005;30:1037-1043.

108. Ahrens J, et al. The nonpsychotropic cannabinoid cannabidiol modulates and directly activates alpha-1 and alpha-1-Beta glycine receptor function. Pharmacology 2009;83:217-222

109. Ross HR, Napier I, Connor M. Inhibition of recombinant human T-type calcium channels by Delta9-tetrahydrocannabinol and cannabidiol. J Biol Chem 2008;283: 16124-16134.

110. Drysdale AJ, et al. Cannabidiol-induced intracellular Ca2+ elevations in hippocampal cells. Neuropharmacology 2006;50:621631.

111. Ryan D, et al. Cannabidiol targets mitochondria to regulate intracellular Ca2+ levels. J Neurosci 2009;29:2053-2063.

112. Rimmerman N, et al. The non-psychoactive plant cannabinoid, cannabidiol affects cholesterol metabolism-related genes in microglial cells. Cell Mol Neurobiol 2011; 31:921-930.
113. Ross RA. The enigmatic pharmacology of GPR55. Trends Pharmacol Sci 2009;30: 156-163.

114. Ryberg E, et al. The orphan receptor GPR55 is a novel cannabinoid receptor. Br J Pharmacol 2007;152:1092-1101.

115. Lauckner JE, et al. GPR55 is a cannabinoid receptor that increases intracellular calcium and inhibits M current. Proc Natl Acad Sci U S A 2008;105:2699-2704

116. Oka S, et al. Identification of GPR55 as a lysophosphatidylinositol receptor. Biochem Biophys Res Commun 2007;362:928-934.

117. Sylantyev S, et al. Cannabinoid- and lysophosphatidylinositolsensitive receptor GPR55 boosts neurotransmitter release at central synapses. Proc Natl Acad Sci U S A 2013;110:5193-5198.

118. Carrier EJ, Auchampach JA, Hillard CJ. Inhibition of an equilibrative nucleoside transporter by cannabidiol: a mechanism of cannabinoid immunosuppression. Proc Natl Acad Sci U S A 2006;103:7895-7900.

119. Pandolfo P, et al. Cannabinoids inhibit the synaptic uptake of adenosine and dopamine in the rat and mouse striatum. Eur $\mathrm{J}$ Pharmacol 2011;655:38-45.

120. Ferre $\mathrm{S}$, et al. Adenosine-cannabinoid receptor interactions. Implications for striatal function. Br J Pharmacol 2010;160:443453.

121. De Petrocellis L, Di Marzo V. Non-CB1, non-CB2 receptors for endocannabinoids, plant cannabinoids, and synthetic cannabimimetics: focus on G-protein-coupled receptors and transient receptor potential channels. J Neuroimmune Pharmacol 2010;5:103-121.

122. Booz GW. Cannabidiol as an emergent therapeutic strategy for lessening the impact of inflammation on oxidative stress. Free Radic Biol Med 2011;51:1054-1061.

123. Hampson AJ, et al. Neuroprotective antioxidants from marijuana. Ann N Y Acad Sci 2000;899:274-282.

124. Liou GI, et al. Mediation of cannabidiol anti-inflammation in the retina by equilibrative nucleoside transporter and $\mathrm{A} 2 \mathrm{~A}$ adenosine receptor. Invest Ophthalmol Vis Sci 2008;49:5526-5531.

125. Hayakawa K, et al. Delayed treatment with cannabidiol has a cerebroprotective action via a cannabinoid receptor-independent myeloperoxidase-inhibiting mechanism. J Neurochem 2007;102: 1488-1496.

126. Hayakawa K, et al. Therapeutic time window of cannabidiol treatment on delayed ischemic damage via high-mobility group box1inhibiting mechanism. Biol Pharm Bull 2009;32:1538-1544.

127. Iuvone T, et al. Neuroprotective effect of cannabidiol, a nonpsychoactive component from Cannabis sativa, on betaamyloid-induced toxicity in PC12 cells. J Neurochem 2004;89: 134-141.

128. Esposito G, et al. Cannabidiol inhibits inducible nitric oxide synthase protein expression and nitric oxide production in betaamyloid stimulated PC12 neurons through p38 MAP kinase and NF-kappaB involvement. Neurosci Lett 2006;399:91-95.

129. Esposito $\mathrm{G}$, et al. Cannabidiol in vivo blunts beta-amyloid induced neuroinflammation by suppressing IL-1beta and iNOS expression. Br J Pharmacol 2007;151:1272-1279.

130. Pietr M, et al. Differential changes in GPR55 during microglial cell activation. FEBS Lett 2009;583:2071-2076.

131. Staton PC, et al. The putative cannabinoid receptor GPR55 plays a role in mechanical hyperalgesia associated with inflammatory and neuropathic pain. Pain 2008;139: 225-236.

132. Ben-Shabat $\mathrm{S}$, et al. An entourage effect: inactive endogenous fatty acid glycerol esters enhance 2-arachidonoyl-glycerol cannabinoid activity. Eur J Pharmacol 1998;353: 23-31.

133. Wagner H, Ulrich-Merzenich G. Synergy research: approaching a new generation of phytopharmaceuticals. Phytomedicine 2009; 16:97-110. 
134. Mechoulam R, Ben-Shabat S. From gan-zi-gun-nu to anandamide and 2-arachidonoylglycerol: the ongoing story of cannabis. Nat Prod Rep 1999;16:131-143.

135. Russo EB. Taming THC: potential cannabis synergy and phytocannabinoid-terpenoid entourage effects. Br J Pharmacol 2011;163:1344-1364.

136. Karniol IG, Carlini EA. Pharmacological interaction between cannabidiol and delta 9-tetrahydrocannabinol. Psychopharmacologia 1973;33:53-70.

137. Englund A, et al. Cannabidiol inhibits THC-elicited paranoid symptoms and hippocampal-dependent memory impairment. J Psychopharmacol 2013;27:19-27.

138. Russo E, Guy GW. A tale of two cannabinoids: the therapeutic rationale for combining tetrahydrocannabinol and cannabidiol. Med Hypotheses 2006;66:234-246.

139. Schubart CD, et al. Cannabis with high cannabidiol content is associated with fewer psychotic experiences. Schizophr Res 2011;130:216-221.

140. Hemaiswarya S, Kruthiventi AK, Doble M. Synergism between natural products and antibiotics against infectious diseases. Phytomedicine 2008;15:639-652.

141. Tallarida RJ. Quantitative methods for assessing drug synergism. Genes Cancer 2011; 2:1003-1008.

142. Hill AJ, et al. Phytocannabinoids as novel therapeutic agents in CNS disorders. Pharmacol Ther 2012;133:79-97.

143. Raol YH, Brooks-Kayal AR. Experimental models of seizures and epilepsies. Prog Mol Biol Transl Sci 2012;105:57-82.

144. Loscher W. Critical review of current animal models of seizures and epilepsy used in the discovery and development of new antiepileptic drugs. Seizure 2011;20:359-368.

145. Simonato $\mathrm{M}$, et al. The challenge and promise of anti-epileptic therapy development in animal models. Lancet Neurol 2014;13: 949-960.

146. Marsicano G, et al. CB1 cannabinoid receptors and on-demand defense against excitotoxicity. Science 2003;302:84-88.

147. Wallace MJ, et al. The endogenous cannabinoid system regulates seizure frequency and duration in a model of temporal lobe epilepsy. J Pharmacol Exp Ther 2003;307: 129-137.

148. Karanian DA, et al. Endocannabinoid enhancement protects against kainic acid-induced seizures and associated brain damage. J Pharmacol Exp Ther 2007;322: 1059-1066.

149. Karanian DA, et al. Dual modulation of endocannabinoid transport and fatty acid amide hydrolase protects against excitotoxicity. J Neurosci 2005;25:7813-7820.

150. Naidoo V, et al. Equipotent inhibition of fatty acid amide hydrolase and monoacylglycerol lipase-dual targets of the endocannabinoid system to protect against seizure pathology. Neurotherapeutics 2012;9:801-813.

151. Deshpande LS, et al. Endocannabinoids block status epilepticus in cultured hippocampal neurons. Eur J Pharmacol 2007;558:52-59.

152. Monory $\mathrm{K}$, et al. The endocannabinoid system controls key epileptogenic circuits in the hippocampus. Neuron 2006;51:455-466.

153. Guggenhuber $\mathrm{S}$, et al. AAV vector-mediated overexpression of CB1 cannabinoid receptor in pyramidal neurons of the hippocampus protects against seizure-induced excitoxicity. PLoS One 2010;5:e15707.

154. Alger BE. Seizing an opportunity for the endocannabinoid system. Epilepsy Curr 2014; 14:272-276.

155. Falenski KW, et al. Status epilepticus causes a long-lasting redistribution of hippocampal cannabinoid type 1 receptor expression and function in the rat pilocarpine model of acquired epilepsy. Neuroscience 2007;146:1232-1244.

156. Falenski KW, et al. Temporal characterization of changes in hippocampal cannabinoid $\mathrm{CB}(1)$ receptor expression following pilocarpine-induced status epilepticus. Brain Res 2009;1262:6472.
157. Bhaskaran MD, Smith BN. Cannabinoid-mediated inhibition of recurrent excitatory circuitry in the dentate gyrus in a mouse model of temporal lobe epilepsy. PLoS One 2010;5:e10683.

158. Sayers KW, et al. Statistical parametric mapping reveals regional alterations in cannabinoid CB1 receptor distribution and G-protein activation in the 3D reconstructed epileptic rat brain. Epilepsia 2012;53:897-907.

159. Ludanyi A, et al. Downregulation of the CB1 cannabinoid receptor and related molecular elements of the endocannabinoid system in epileptic human hippocampus. J Neurosci 2008;28:2976-2990.

160. Romigi A, et al. Cerebrospinal fluid levels of the endocannabinoid anandamide are reduced in patients with untreated newly diagnosed temporal lobe epilepsy. Epilepsia 2010;51:768-772.

161. Wyeth MS, et al. Selective reduction of cholecystokinin-positive basket cell innervation in a model of temporal lobe epilepsy. J Neurosci 2010;30:8993-9006.

162. Sun C, et al. Loss of cholecystokinin-containing terminals in temporal lobe epilepsy. Neurobiol Dis 2014;62:44-55.

163. Karlocai MR, et al. Redistribution of CB1 cannabinoid receptors in the acute and chronic phases of pilocarpine-induced epilepsy. PLoS One 2011;6:e27196.

164. Magloczky Z, et al. Dynamic changes of CB1-receptor expression in hippocampi of epileptic mice and humans. Epilepsia 2010;51(Suppl. 3):115-120.

165. Chen K, et al. Long-term plasticity of endocannabinoid signaling induced by developmental febrile seizures. Neuron 2003;39:599611.

166. Chen K, et al. Prevention of plasticity of endocannabinoid signaling inhibits persistent limbic hyperexcitability caused by developmental seizures. J Neurosci 2007;27: 46-58.

167. Hill AJ, Hill TD, Whalley B. The development of cannabinoid based therapies for epilepsy. In: Murillo-Rodriguez (Ed.) Endocannabinoids: molecular, pharmacological, behavioral and clinical features. bentham science publishers, Oak Park, IL, 2013, pp 164-204

168. Manna SS, Umathe SN. Involvement of transient receptor potential vanilloid type 1 channels in the pro-convulsant effect of anandamide in pentylenetetrazole-induced seizures. Epilepsy Res 2012;100:113-124.

169. Luszczki JJ, et al. Arachidonyl-2'-chloroethylamide, a highly selective cannabinoid CB1 receptor agonist, enhances the anticonvulsant action of valproate in the mouse maximal electroshockinduced seizure model. Eur J Pharmacol 2006;547:65-74.

170. Luszczki JJ, et al. Effect of arachidonyl-2'-chloroethylamide, a selective cannabinoid CB1 receptor agonist, on the protective action of the various antiepileptic drugs in the mouse maximal electroshock-induced seizure model. Prog Neuropsychopharmacol Biol Psychiatry 2010;34:18-25.

171. Luszczki JJ, et al. Synthetic cannabinoid WIN 55,212-2 mesylate enhances the protective action of four classical antiepileptic drugs against maximal electroshock-induced seizures in mice. Pharmacol Biochem Behav 2011;98:261-267.

172. Luszczki JJ, et al. Effects of WIN 55,212-2 mesylate (a synthetic cannabinoid) on the protective action of clonazepam, ethosuximide, phenobarbital and valproate against pentylenetetrazole-induced clonic seizures in mice. Prog Neuropsychopharmacol Biol Psychiatry 2011;35:1870-1876.

173. Andres-Mach M, et al. Effect of ACEA-a selective cannabinoid CB1 receptor agonist on the protective action of different antiepileptic drugs in the mouse pentylenetetrazole-induced seizure model. Prog Neuropsychopharmacol Biol Psychiatry 2012;39: 301-309.

174. Luszczki JJ, et al. Effects of WIN 55,212-2 mesylate on the anticonvulsant action of lamotrigine, oxcarbazepine, pregabalin and topiramate against maximal electroshock-induced seizures in mice. Eur J Pharmacol 2013;720:247-254. 
175. Florek-Luszczki M, et al. Effects of WIN 55,212-2 (a nonselective cannabinoid $\mathrm{CB} 1$ and $\mathrm{CB} 2$ receptor agonist) on the protective action of various classical antiepileptic drugs in the mouse $6 \mathrm{~Hz}$ psychomotor seizure model. J Neural Transm 2014;121: 707-715.

176. Florek-Luszczki M, Zagaja M, Luszczki JJ. Influence of WIN 55, 212-2 on the anticonvulsant and acute neurotoxic potential of clobazam and lacosamide in the maximal electroshock-induced seizure model and chimney test in mice. Epilepsy Res 2014;108: 1728-1733.

177. Florek-Luszczki M, et al. Effects of WIN 55,212-2 (a synthetic cannabinoid CB1 and CB2 receptor agonist) on the anticonvulsant activity of various novel antiepileptic drugs against $6 \mathrm{~Hz}$-induced psychomotor seizures in mice. Pharmacol Biochem Behav 2015; 130:53-58.

178. Chesher GB, Jackson DM. The effect of withdrawal from cannabis on pentylenetetrazol convulsive threshold in mice. Psychopharmacologia 1974;40: 129-135.

179. Chesher GB, Jackson DM, Malor RM. Interaction of delta9tetrahydrocannabinol and cannabidiol with phenobarbitone in protecting mice from electrically induced convulsions. J Pharm Pharmacol 1975;27:608-609.

180. National Toxicology Program. NTP toxicology and carcinogenesis studies of 1-trans-delta(9)-tetrahydrocannabinol (CAS No. 1972-08-3) in F344 rats and B6C3F1 mice (gavage studies). Natl Toxicol Program Tech Rep Ser 1996;446:1-317.

181. Hill AJ, et al. Cannabidivarin is anticonvulsant in mouse and rat. Br J Pharmacol 2012;167:1629-1642.

182. Oviedo A, Glowa J, Herkenham M. Chronic cannabinoid administration alters cannabinoid receptor binding in rat brain: a quantitative autoradiographic study. Brain Res 1993;616:293-302.

183. Rodriguez de Fonseca F, et al. Downregulation of rat brain cannabinoid binding sites after chronic delta 9-tetrahydrocannabinol treatment. Pharmacol Biochem Behav 1994;47:33-40.

184. Sim LJ, et al. Effects of chronic treatment with delta9tetrahydrocannabinol on cannabinoid-stimulated [35S]GTPgammaS autoradiography in rat brain. J Neurosci 1996;16:8057-8066.

185. Fan F, et al. Cannabinoid receptor down-regulation without alteration of the inhibitory effect of CP 55,940 on adenylyl cyclase in the cerebellum of CP 55,940-tolerant mice. Brain Res 1996;706: 13-20.

186. Romero J, et al. Effects of chronic exposure to delta9tetrahydrocannabinol on cannabinoid receptor binding and mRNA levels in several rat brain regions. Brain Res Mol Brain Res 1997;46:100-108.

187. Romero J, et al. Autoradiographic analysis of cannabinoid receptor binding and cannabinoid agonist-stimulated [35S]GTP gamma $\mathrm{S}$ binding in morphine-dependent mice. Drug Alcohol Depend 1998;50:241-249.

188. Romero J, et al. Cannabinoid receptor and WIN-55,212-2-stimulated [35S]GTP gamma S binding and cannabinoid receptor mRNA levels in the basal ganglia and the cerebellum of adult male rats chronically exposed to delta 9-tetrahydrocannabinol. J Mol Neurosci 1998;11:109-119.

189. Romero J, et al. Time-course of the cannabinoid receptor downregulation in the adult rat brain caused by repeated exposure to delta9-tetrahydrocannabinol. Synapse 1998;30:298-308.

190. Zhuang S, et al. Effects of long-term exposure to delta9-THC on expression of cannabinoid receptor (CB1) mRNA in different rat brain regions. Brain Res Mol Brain Res 1998;62:141-149.

191. Hsieh C, et al. Internalization and recycling of the CB1 cannabinoid receptor. J Neurochem 1999;73:493-501.

192. Corchero J, et al. Time-dependent differences of repeated administration with Delta9-tetrahydrocannabinol in proenkephalin and cannabinoid receptor gene expression and G-protein activation by mu-opioid and CB1-cannabinoid receptors in the caudateputamen. Brain Res Mol Brain Res 1999;67:148-157.

193. Breivogel CS, et al. Chronic delta9-tetrahydrocannabinol treatment produces a time-dependent loss of cannabinoid receptors and cannabinoid receptor-activated $\mathrm{G}$ proteins in rat brain. $\mathrm{J}$ Neurochem 1999;73:2447-2459.

194. Breivogel CS, et al. The effects of delta9-tetrahydrocannabinol physical dependence on brain cannabinoid receptors. Eur J Pharmacol 2003;459:139-150.

195. McKinney DL, et al. Dose-related differences in the regional pattern of cannabinoid receptor adaptation and in vivo tolerance development to delta9-tetrahydrocannabinol. J Pharmacol Exp Ther 2008;324:664-673.

196. Sim-Selley LJ, Martin BR. Effect of chronic administration of R(+)-[2,3-Dihydro-5-methyl-3-[(morpholinyl)methyl]pyrrolo[1,2, 3-de]-1,4-benzoxaz inyl]-(1-naphthalenyl)methanone mesylate (WIN55,212-2) or delta(9)-tetrahydrocannabinol on cannabinoid receptor adaptation in mice. J Pharmacol Exp Ther 2002;303:3644.

197. Sim-Selley LJ. Regulation of cannabinoid CB1 receptors in the central nervous system by chronic cannabinoids. Crit Rev Neurobiol 2003;15:91-119.

198. Sim-Selley LJ, et al. Prolonged recovery rate of CB1 receptor adaptation after cessation of long-term cannabinoid administration. Mol Pharmacol 2006;70:986-996.

199. Martin BR, Sim-Selley LJ, Selley DE. Signaling pathways involved in the development of cannabinoid tolerance. Trends Pharmacol Sci 2004;25:325-330.

200. Villares J. Chronic use of marijuana decreases cannabinoid receptor binding and mRNA expression in the human brain. Neuroscience 2007;145:323-334.

201. Coutts AA, et al. Agonist-induced internalization and trafficking of cannabinoid CB1 receptors in hippocampal neurons. J Neurosci 2001;21:2425-2433.

202. Lundberg DJ, Daniel AR, Thayer SA. Delta(9)Tetrahydrocannabinol-induced desensitization of cannabinoidmediated inhibition of synaptic transmission between hippocampal neurons in culture. Neuropharmacology 2005;49:1170-1177.

203. Deshpande LS, Blair RE, DeLorenzo RJ. Prolonged cannabinoid exposure alters GABA(A) receptor mediated synaptic function in cultured hippocampal neurons. Exp Neurol 2011;229:264-273.

204. Dewey WL. Cannabinoid pharmacology. Pharmacol Rev 1986;38:151-178.

205. Abood ME, et al. Development of behavioral tolerance to delta 9THC without alteration of cannabinoid receptor binding or mRNA levels in whole brain. Pharmacol Biochem Behav 1993;46:575579.

206. Ten Ham M, Loskota WJ, Lomax P. Acute and chronic effects of beta9-tetrahydrocannabinol on seizures in the gerbil. Eur J Pharmacol 1975;31:148-152.

207. Corcoran ME, McCaughran JA, Jr., Wada JA, Antiepileptic and prophylactic effects of tetrahydrocannabinols in amygdaloid kindled rats. Epilepsia 1978;19: 47-55.

208. Colasanti BK, Lindamood C, 3rd, Craig CR. Effects of marihuana cannabinoids on seizure activity in cobalt-epileptic rats. Pharmacol Biochem Behav 1982;16: 573-578.

209. Karler R, Turkanis SA. Subacute cannabinoid treatment: anticonvulsant activity and withdrawal excitability in mice. Br J Pharmacol 1980;68:479-484.

210. Blair RE, et al. Prolonged exposure to WIN55,212-2 causes downregulation of the $\mathrm{CB} 1$ receptor and the development of tolerance to its anticonvulsant effects in the hippocampal neuronal culture model of acquired epilepsy. Neuropharmacology 2009;57:208218.

211. Jones RT, Benowitz N, Bachman J. Clinical studies of cannabis tolerance and dependence. Ann N Y Acad Sci 1976;282:221-239. 
212. Jones RT, Benowitz NL, Herning RI. Clinical relevance of cannabis tolerance and dependence. J Clin Pharmacol 1981;21(8-9 Suppl.):143S-152S.

213. Kirk JM, de Wit H. Responses to oral delta9-tetrahydrocannabinol in frequent and infrequent marijuana users. Pharmacol Biochem Behav 1999;63:137-142

214. Hart CL, et al. Comparison of smoked marijuana and oral Delta(9)-tetrahydrocannabinol in humans. Psychopharmacology (Berl) 2002;164:407-415.

215. Babor TF, et al. Marijuana consumption and tolerance to physiological and subjective effects. Arch Gen Psychiatry 1975;32:15481552.

216. Nowlan R, Cohen S. Tolerance to marijuana: heart rate and subjective "high". Clin Pharmacol Ther 1977;22:550-556.

217. Aceto $\mathrm{MD}$, et al. Cannabinoid precipitated withdrawal by the selective cannabinoid receptor antagonist, SR 141716A. Eur J Pharmacol 1995;282:R1-R2.

218. Tsou K, Patrick SL, Walker JM. Physical withdrawal in rats tolerant to delta 9-tetrahydrocannabinol precipitated by a cannabinoid receptor antagonist. Eur J Pharmacol 1995;280:R13-R15.

219. Rodriguez de Fonseca F, et al. Activation of corticotropinreleasing factor in the limbic system during cannabinoid withdrawal. Science 1997;276:2050-2054.

220. Kaymakcalan S. Tolerance to and dependence on cannabis. Bull Narc 1973;25:39-47.

221. Beardsley PM, Balster RL, Harris LS. Dependence on tetrahydrocannabinol in rhesus monkeys. J Pharmacol Exp Ther 1986;239: 311-319.

222. Budney AJ, Hughes JR. The cannabis withdrawal syndrome. Curr Opin Psychiatry 2006;19:233-238.

223. Karler R, et al. Interaction between delta-9-tetrahydrocannabinol and kindling by electrical and chemical stimuli in mice. Neuropharmacology 1984;23:1315-1320.

224. Karler R, Calder LD, Turkanis SA. Prolonged CNS hyperexcitability in mice after a single exposure to delta-9-tetrahydrocannabinol. Neuropharmacology 1986;25:441-446.

225. Hegde M, et al. Seizure exacerbation in two patients with focal epilepsy following marijuana cessation. Epilepsy Behav 2012;25: 563-566.

226. Ellison JM, Gelwan E, Ogletree J. Complex partial seizure symptoms affected by marijuana abuse. J Clin Psychiatry 1990;51:439440 .

227. Leite JR, Carlini EA. Failure to obtain "cannabis-directed behavior" and abstinence syndrome in rats chronically treated with cannabis sativa extracts. Psychopharmacologia 1974;36:133-145.

228. Robson P. Abuse potential and psychoactive effects of delta-9tetrahydrocannabinol and cannabidiol oromucosal spray (Sativex), a new cannabinoid medicine. Expert Opin Drug Saf 2011;10:675-685.

229. Wade DT, et al. Do cannabis-based medicinal extracts have general or specific effects on symptoms in multiple sclerosis? A double-blind, randomized, placebo-controlled study on 160 patients. Mult Scler 2004;10:434-441.

230. Russo EB, Guy GW, Robson PJ. Cannabis, pain, and sleep: lessons from therapeutic clinical trials of Sativex, a cannabis-based medicine. Chem Biodivers 2007; 4:1729-1743.

231. Rog DJ, Nurmikko TJ, Young CA. Oromucosal delta9-tetrahydrocannabinol/cannabidiol for neuropathic pain associated with multiple sclerosis: an uncontrolled, open-label, 2-year extension trial. Clin Ther 2007;29: 2068-2079.

232. Perez J. Combined cannabinoid therapy via an oromucosal spray. Drugs Today (Barc) 2006;42:495-503.

233. Crippa JA, et al. Cannabidiol for the treatment of cannabis withdrawal syndrome: a case report. J Clin Pharm Ther 2013;38:162164
234. Allsop DJ, et al. Nabiximols as an agonist replacement therapy during cannabis withdrawal: a randomized clinical trial. JAMA Psychiatry 2014;71:281-291.

235. Allsop DJ, Lintzeris N, Copeland J, Dunlop A, McGregor IS. Cannabinoid replacement therapy (CRT): Nabiximols (Sativex) as a novel treatment for cannabis withdrawal. Clin Pharmacol Ther 2015;97:571-574.

236. Keeler MH, Reifler CB. Grand mal convulsions subsequent to marijuana use. Case report. Dis Nerv Syst 1967;28:474-475.

237. Lapoint J, et al. Severe toxicity following synthetic cannabinoid ingestion. Clin Toxicol (Phila) 2011;49:760-764.

238. Jinwala FN, Gupta M. Synthetic cannabis and respiratory depression. J Child Adolesc Psychopharmacol 2012;22:459-462.

239. Hermanns-Clausen $\mathrm{M}$, et al. Acute intoxication by synthetic cannabinoids_-four case reports. Drug Test Anal 2013;5:790-794.

240. Hermanns-Clausen M, et al. Acute toxicity due to the confirmed consumption of synthetic cannabinoids: clinical and laboratory findings. Addiction 2013;108: 534-544.

241. McQuade D, et al. First European case of convulsions related to analytically confirmed use of the synthetic cannabinoid receptor agonist AM-2201. Eur J Clin Pharmacol 2013; 69:373-376.

242. Pant S, et al. Spicy seizure. Am J Med Sci 2012;344:67-68.

243. Tofighi B, Lee JD. Internet highs - seizures after consumption of synthetic cannabinoids purchased online. J Addict Med 2012;6: 240-241.

244. de Havenon A, et al. The secret "spice": an undetectable toxic cause of seizure. Neurohospitalist 2011;1:182-186.

245. Castaneto MS, et al. Synthetic cannabinoids: epidemiology, pharmacodynamics, and clinical implications. Drug Alcohol Depend 2014; 144:12-41.

246. Davis JP, Ramsey HH. Anti-epileptic action of marijuana-active substances. Fed Proc Am Soc Exp Biol 1949;8:284.

247. Consroe PF, Wood GC, Buchsbaum H. Anticonvulsant nature of marihuana smoking. JAMA 1975;234:306-307.

248. Lorenz R. On the application of cannabis in paediatrics and epileptology. Neuro Endocrinol Lett 2004;25:40-44.

249. Mortati K, Dworetzky B, Devinsky O. Marijuana: an effective antiepileptic treatment in partial epilepsy? A case report and review of the literature. Rev Neurol Dis 2007;4:103-106.

250. Gordon E, Devinsky O. Alcohol and marijuana: effects on epilepsy and use by patients with epilepsy. Epilepsia 2001;42:12661272.

251. Maa E, Figi P. The case for medical marijuana in epilepsy. Epilepsia 2014;55: 783-786.

252. Corral VJ. Differential effects of medical marijuana based on strain and route of administration: a three-year observational study. J Cannabis Ther 2001;1:43-59.

253. Hamerle M, et al. Cannabis and other illicit drug use in epilepsy patients. Eur J Neurol, 2014;21:167-170.

254. Gieringer D. Madical use of cannabis: experience in California. Haworth Press, Binghamton, NY, 2001.

255. Feeney D, Spiker M. Marijuana and epilepsy: activation of symptoms by delta-9-THC. In: C.S and S.RC (Eds.). The therapeutic potential of marihuana. Plenum Press, New York, 1976.

256. Alldredge BK, Lowenstein DH, Simon RP. Seizures associated with recreational drug abuse. Neurology 1989;39:1037-1039.

257. Brust JC, et al. Marijuana use and the risk of new onset seizures. Trans Am Clin Climatol Assoc 1992;103:176-181.

258. Gross DW, et al. Marijuana use and epilepsy: prevalence in patients of a tertiary care epilepsy center. Neurology 2004;62:20952097.

259. Porter BE, Jacobson C. Report of a parent survey of cannabidiolenriched cannabis use in pediatric treatment-resistant epilepsy. Epilepsy Behav 2013;29:574-577. 
260. Press CA, Knupp KG, Chapman KE. Parental reporting of response to oral cannabis extracts for treatment of refractory epilepsy. Epilepsy Behav 2015;45: 49-52.

261. Mechoulam R, Carlini EA. Toward drugs derived from cannabis. Naturwissenschaften 1978;65:174-179.

262. Cunha JM, et al. Chronic administration of cannabidiol to healthy volunteers and epileptic patients. Pharmacology 1980;21:175185.

263. Ames FR, Cridland S. Anticonvulsant effect of cannabidiol. S Afr Med J 1986; 69:14.

264. Trembly B, Sherman M. Double-blind clinical study of cannabidiol as a secondary anticonvulsant. In: Marijuana '90 international conference on cannabis and cannabinoids, Kolympari, Crete, 1990.

265. van Rijckevorsel K. Treatment of Lennox-Gastaut syndrome: overview and recent findings. Neuropsychiatr Dis Treat 2008;4: 1001-1019.

266. Dravet C. The core Dravet syndrome phenotype. Epilepsia 2011;52(Suppl. 2):3-9.

267. Mathern GW, Beninsig L, Nehlig A. Fewer specialists support using medical marijuana and CBD in treating epilepsy patients compared with other medical professionals and patients: result of Epilepsia's survey. Epilepsia 2015;56:1-6.

268. Volkow ND, Compton WM, Weiss SR. Adverse health effects of marijuana use. N Engl J Med 2014;371:879.

269. Morales-Munoz I, et al. Characterizing cannabis-induced psychosis: a study with prepulse inhibition of the startle reflex. Psychiatry Res 2014;220:535-540.

270. Lynskey M, Hall W. The effects of adolescent cannabis use on educational attainment: a review. Addiction 2000;95:1621-1630.

271. Crean RD, Crane NA, Mason BJ. An evidence based review of acute and long-term effects of cannabis use on executive cognitive functions. J Addict Med 2011;5: 1-8.

272. Lisdahl KM, et al. Dare to delay? The impacts of adolescent alcohol and marijuana use onset on cognition, brain structure, and function. Front Psychiatry 2013;4:53.

273. Crane NA, Schuster RM, Gonzalez R. Preliminary evidence for a sex-specific relationship between amount of cannabis use and neurocognitive performance in young adult cannabis users. J Int Neuropsychol Soc 2013;19:1009-1015.

274. Jacobus J, et al. Cortical thickness and neurocognition in adolescent marijuana and alcohol users following 28 days of monitored abstinence. J Stud Alcohol Drugs 2014; 75:729-743.

275. Gilman JM, et al. Cannabis use is quantitatively associated with nucleus accumbens and amygdala abnormalities in young adult recreational users. J Neurosci 2014;34: 5529-5538.

276. Gruber SA, et al. Worth the wait: effects of age of onset of marijuana use on white matter and impulsivity. Psychopharmacology (Berl) 2014;231:1455-1465.

277. Tortoriello G, et al. Miswiring the brain: Delta9tetrahydrocannabinol disrupts cortical development by inducing an SCG10/stathmin-2 degradation pathway. EMBO J 2014;33: 668-685.

278. Raver SM, Haughwout SP, Keller A. Adolescent cannabinoid exposure permanently suppresses cortical oscillations in adult mice. Neuropsychopharmacology 2013;38:2338-2347.

279. Raver SM, Keller A. Permanent suppression of cortical oscillations in mice after adolescent exposure to cannabinoids: receptor mechanisms. Neuropharmacology 2014;86:161-173.

280. Houck JM, Bryan AD, Feldstein Ewing SW. Functional connectivity and cannabis use in high-risk adolescents. Am J Drug Alcohol Abuse 2013;39:414-423.

281. Pavisian B, et al. Effects of cannabis on cognition in patients with MS: a psychometric and MRI study. Neurology 2014;82:18791887.
282. Guy GW, Robson PJ. A phase I, open label, four-way crossover study to compare the pharmacokinetic profiles of a single dose of $20 \mathrm{mg}$ of a cannabis based medicine extract (CBME) administered on 3 different areas of the buccal mucosa and to investigate the pharmacokinetics of CBME per oral in healthy male and female volunteers (GWPK0112). J Cannabis Ther 2003;3:79-120.

283. Hawksworth G, McArdle K. Metabolism and pharmacokinetics of cannabinoids. Pharmaceutical Press, London, 2004.

284. Bornheim LM, et al. Characterization of cannabidiol-mediated cytochrome P450 inactivation. Biochem Pharmacol 1993;45: 1323-1331.

285. Yamaori S, et al. Cannabidiol, a major phytocannabinoid, as a potent atypical inhibitor for CYP2D6. Drug Metab Dispos 2011;39:2049-2056.

286. Jiang R, et al. Identification of cytochrome P450 enzymes responsible for metabolism of cannabidiol by human liver microsomes. Life Sci 2011;89:165-170.

287. Yamaori S, et al. Potent inhibition of human cytochrome P450 3A isoforms by cannabidiol: role of phenolic hydroxyl groups in the resorcinol moiety. Life Sci 2011;88:730-736.

288. Jiang R, et al. Cannabidiol is a potent inhibitor of the catalytic activity of cytochrome P450 2C19. Drug Metab Pharmacokinet 2013;28:332-338.

289. Stout SM, Cimino NM. Exogenous cannabinoids as substrates, inhibitors, and inducers of human drug metabolizing enzymes: a systematic review. Drug Metab Rev 2014;46:86-95.

290. Patsalos PN, Perucca E. Clinically important drug interactions in epilepsy: interactions between antiepileptic drugs and other drugs. Lancet Neurol 2003;2: 473-481.

291. Yamaori S, et al. Characterization of major phytocannabinoids, cannabidiol and cannabinol, as isoform-selective and potent inhibitors of human CYP1 enzymes. Biochem Pharmacol 2010;79: 1691-1698.

292. Friedman D, et al. The effect of Epidiolex (Cannabidiol) on serum levels of concomminant anti-epileptic drugs in children and young adults with treatment-resistant epilepsy in an expanded access program. In: American Epilepsy Society, Seattle, WA, 2014.

293. Espay AJ, et al. Placebo effect of medication cost in Parkinson disease: a randomized double-blind study. Neurology 2015;84: 794-802.

294. Weimer K, et al. Placebo effects in children: a review. Pediatr Res 2013;74:96-102.

295. Kemeny ME, et al. Placebo response in asthma: a robust and objective phenomenon. J Allergy Clin Immunol 2007;119:13751381.

296. Rheims S, et al. Greater response to placebo in children than in adults: a systematic review and meta-analysis in drug-resistant partial epilepsy. PLoS Med 2008;5: e166.

297. Anon. Double-blind, placebo-controlled evaluation of cinromide in patients with the Lennox-Gastaut Syndrome. The Group for the Evaluation of Cinromide in the Lennox-Gastaut Syndrome. Epilepsia 1989;30:422-429.

298. Rekand T. THC:CBD spray and MS spasticity symptoms: data from latest studies. Eur Neurol 2014;71(Suppl. 1):4-9.

299. Naderi N, et al. Evaluation of interactions between cannabinoid compounds and diazepam in electroshock-induced seizure model in mice. J Neural Transm 2008;115:1501-1511.

300. Naderi N, et al. Modulation of anticonvulsant effects of cannabinoid compounds by GABA-A receptor agonist in acute pentylenetetrazole model of seizure in rat. Neurochem Res 2011;36:1520-1525.

301. Vilela LR, et al. Effects of cannabinoids and endocannabinoid hydrolysis inhibition on pentylenetetrazole-induced seizure and electroencephalographic activity in rats. Epilepsy Res 2013;104: 195-202. 
302. Shubina L, Aliev R, Kitchigina V. Attenuation of kainic acidinduced status epilepticus by inhibition of endocannabinoid transport and degradation in guinea pigs. Epilepsy Res 2015;111:3344.

303. Wendt $\mathrm{H}$, et al. Targeting the endocannabinoid system in the amygdala kindling model of temporal lobe epilepsy in mice. Epilepsia 2011;52:e62-e65.

304. Wallace MJ, et al. Assessment of the role of CB1 receptors in cannabinoid anticonvulsant effects. Eur J Pharmacol 2001;428: 51-57.

305. Payandemehr B, et al. Involvement of PPAR receptors in the anticonvulsant effects of a cannabinoid agonist, WIN 55,212-2. Prog Neuropsychopharmacol Biol Psychiatry 2015;57:140-145.

306. van Rijn CM, et al. WAG/Rij rats show a reduced expression of $\mathrm{CB}(1)$ receptors in thalamic nuclei and respond to the $\mathrm{CB}(1)$ receptor agonist, $\mathrm{R}(+)$ WIN55,212-2, with a reduced incidence of spike-wave discharges. Epilepsia 2010;51:1511-1521.

307. Citraro R, et al. CB1 agonists, locally applied to the corticothalamic circuit of rats with genetic absence epilepsy, reduce epileptic manifestations. Epilepsy Res 2013; 106:74-82.

308. Lambert DM, et al. Anticonvulsant activity of $\mathrm{N}$ palmitoylethanolamide, a putative endocannabinoid, in mice. Epilepsia 2001;42:321-327.

309. Sheerin AH, et al. Selective antiepileptic effects of Npalmitoylethanolamide, a putative endocannabinoid. Epilepsia 2004; 45:1184-1188.

310. Wallace MJ, Martin BR, DeLorenzo RJ. Evidence for a physiological role of endocannabinoids in the modulation of seizure threshold and severity. Eur J Pharmacol 2002;452:295-301.

311. Shafaroodi $\mathrm{H}$, et al. The interaction of cannabinoids and opioids on pentylenetetrazole-induced seizure threshold in mice. Neuropharmacology 2004;47:390-400.

312. Bahremand A, et al. The cannabinoid anticonvulsant effect on pentylenetetrazole-induced seizure is potentiated by ultra-low dose naltrexone in mice. Epilepsy Res 2008;81:44-51.

313. Bahremand A, et al. Involvement of nitrergic system in the anticonvulsant effect of the cannabinoid $\mathrm{CB}(1)$ agonist ACEA in the pentylenetetrazole-induced seizure in mice. Epilepsy Res 2009;84:110-119.

314. Rudenko V, et al. Inverse relationship of cannabimimetic (R+ )WIN 55, 212 on behavior and seizure threshold during the juvenile period. Pharmacol Biochem Behav 2012;100:474-484.

315. Di Maio R, Cannon JR, Timothy Greenamyre J. Post-status epilepticus treatment with the cannabinoid agonist WIN 55,212-2 prevents chronic epileptic hippocampal damage in rats. Neurobiol Dis 2014;73C:356-365.

316. Rizzo V, et al. Evidences of cannabinoids-induced modulation of paroxysmal events in an experimental model of partial epilepsy in the rat. Neurosci Lett 2009;462:135-139.

317. Kow RL, et al. Modulation of pilocarpine-induced seizures by cannabinoid receptor 1. PLoS One 2014;9:e95922.

318. Kozan R, Ayyildiz M, Agar E. The effects of intracerebroventricular AM-251, a CB1-receptor antagonist, and ACEA, a CB1receptor agonist, on penicillin-induced epileptiform activity in rats. Epilepsia 2009;50:1760-1767.

319. Cakil D, et al. The effect of co-administration of the NMDA blocker with agonist and antagonist of CB1-receptor on penicillin-induced epileptiform activity in rats. Epilepsy Res 2011;93:128-137.
320. van Rijn CM, et al. Endocannabinoid system protects against cryptogenic seizures. Pharmacol Rep 2011;63:165-168.

321. Vinogradova LV, Shatskova AB, van Rijn CM. Pro-epileptic effects of the cannabinoid receptor antagonist SR141716 in a model of audiogenic epilepsy. Epilepsy Res 2011;96:250-256.

322. Gholizadeh S, et al. Ultra-low dose cannabinoid antagonist AM251 enhances cannabinoid anticonvulsant effects in the pentylenetetrazole-induced seizure in mice. Neuropharmacology 2007;53:763-770.

323. Dudek FE, et al. The effect of the cannabinoid-receptor antagonist, SR141716, on the early stage of kainate-induced epileptogenesis in the adult rat. Epilepsia 2010;51(Suppl. 3):126-130.

324. Echegoyen J, et al. Single application of a CB1 receptor antagonist rapidly following head injury prevents long-term hyperexcitability in a rat model. Epilepsy Res 2009;85:123-127.

325. Sofia RD, Kubena RK, Barry, H, 3rd. Comparison among four vehicles and four routes for administering delta9-tetrahydrocannabinol. J Pharm Sci 1974;63:939-941.

326. Chesher GB, Jackson DM. Anticonvulsant effects of cannabinoids in mice: drug interactions within cannabinoids and cannabinoid interactions with phenytoin. Psychopharmacologia 1974;37:255264.

327. Johnson DD, et al. Epileptiform seizures in domestic fowl. V. The anticonvulsant activity of delta9-tetrahydrocannabinol. Can J Physiol Pharmacol 1975;53:1007-1013.

328. Wada JA, Osawa T, Corcoran ME. Effects of tetrahydrocannabinols on kindled amygdaloid seizures and photogenic seizures in Senegalese baboons, Papio papio. Epilepsia 1975;16:439-448.

329. Boggan WO, Steele RA, Freedman DX. 9 -Tetrahydrocannabinol effect on audiogenic seizure susceptibility. Psychopharmacologia 1973;29:101-106.

330. Corcoran ME, McCaughran JA, Jr., Wada JA. Acute antiepileptic effects of 9-tetrahydrocannabinol in rats with kindled seizures. Exp Neurol 1973;40:471-483.

331. Wada JA, et al. Antiepileptic and prophylactic effects of tetrahydrocannabinols in amygdaloid kindled cats. Epilepsia 1975;16: 503-510.

332. Turkanis SA, et al. An electrophysiological analysis of the anticonvulsant action of cannabidiol on limbic seizures in conscious rats. Epilepsia 1979;20:351-363.

333. Izquierdo I, Orsingher OA, Berardi AC. Effect of cannabidiol and of other cannabis sativa compounds on hippocampal seizure discharges. Psychopharmacologia 1973;28:95-102.

334. Karler R, Turkanis SA. Cannabis and epilepsy. Adv Biosci 1978;22-23:619-641.

335. Consroe P, et al. Effects of cannabidiol on behavioral seizures caused by convulsant drugs or current in mice. Eur J Pharmacol 1982;83:293-298.

336. Shirazi-zand $Z$, et al. The role of potassium BK channels in anticonvulsant effect of cannabidiol in pentylenetetrazole and maximal electroshock models of seizure in mice. Epilepsy Behav 2013;28:1-7.

337. Hill TD, et al. Cannabidivarin-rich cannabis extracts are anticonvulsant in mouse and rat via a CB1 receptor-independent mechanism. Br J Pharmacol 2013;170:679-692.

338. Jones NA, et al. Cannabidiol exerts anti-convulsant effects in animal models of temporal lobe and partial seizures. Seizure 2012;21:344-352. 